\title{
LONG-TERM ATHLETE DEVELOPMENT, FROM THEORETICAL AND PRACTICAL MODEL TO COGNITIVE PROBLEM
}

\section{DESARROLLO A LARGO PLAZO DEL DEPORTISTA, DESDE EL MODELO TEÓRICO Y PRÁCTICO HASTA EL PROBLEMA COGNITIVO}

\author{
Robert Ropret, Branislav Jevtić \\ Faculty of Sport and Physical Education, University of Belgrade, Serbia
}

\begin{abstract}
Two decades after designing and implementing the course of Children's sport as a university subject at the Faculty of Sports and Physical Education, University of Belgrade, and its full academic and practical affirmation, the question of revising and expanding the theoretical and practical context of this subject has been raised, especially in the area of knowledge-related to long-term development of an athlete (DRS) and career planning (problem of this paper). Therefore, theoretical and practical models related to DRS have been introduced as the subject of this analysis, and as a function of theoretical and practical verification, related to defining the context of a new cognitive problem. If we summarize the extensive theoretical and practical sources, we can conclude that sport theory is not capable to creating a framework for a realistic, much less a long-term athlete development model, which is why the aim of this paper is to set out the theoretical and empirical trends towards a new paradigm for holistic view of DRS through sport. An essential and thorough analysis of the context of a representative model of long-term development of an athlete, known by its English acronym „LATD and other DRS models ascertained that their starting point should be established around the concept of "physical literacy", as well as that the truth of the DRS model is still in the process of theoretical and practical verification. The discussion offered is a framework for new strides in approach to a comprehensive theory and practice of sport, especially in the area of children's and youth sport.
\end{abstract}

Key words: LONG-TERM ATHLETE DEVELOPMENT /

\section{LTAD / THEORETICAL AND PRACTICAL REDUCTIONS / PHYSICAL LITERACY}

\section{EXTRACTO}

Después de dos décadas desde la creación y establecimiento del deporte infantil como una asignatura en la Facultad de Deporte y Educación Física de la Universidad en Belgrado y de su plena afirmación académica y práctica, surgió la pregunta de revisión y ampliación del contexto teórico y práctico de esta asignatura, sobre todo en el espacio de cognición que se refiere al desarrollo a largo plazo del deportista (DLPD) y la planificación de la carrera (problema de trabajo). Por eso, como el objeto de este análisis se impusieron los modelos teóricos y prácticos que se refieren al DLPD y en función de la verificación teórica y práctica, es decir en dirección de definir contexto del nuevo problema cognitivo. Resumiendo el material teórico y práctico voluminoso se llegó a la conclusión que la teoría del deporte no tiene posibilidad de hacer un marco para el modelo real y menos completo del desarrollo a largo plazo del deportista, por lo que como el objetivo del presente trabajo se establece el movimiento teórico y empírico hacia una nueva paradigma de la percepción del DLPD a través del deporte. Por un análisis esencial y básico del contexto del modelo representativo, conocido por su acrónimo inglés "LATD” (Long Term Athlet Development), como también de otros modelos del desarrollo a largo plazo del deportista, se concluyó que su punto de partida tiene que establecerse alrededor del concepto "alfabetismo físico", así como que la veracidad del modelo DLPD sigue estando en el procedimiento de la verificación teórica y práctica. El debate ofrecido es el marco para dar nuevos pasos en enfocar la teoría y práctica completa del deporte sobre todo en la parte del deporte infantil y juvenil.

Palabras claves: DESARROLLO A LARGO PLAZO DEL DEPORTISTA / LATD / REDUCCIONES TEÓRICAS Y PRACTICAS / ALFABETISMO FÍSICO 


\section{INTRODUCTION}

The rich sporting practice together with the numerous results of research, indicate that a child starts playing sports primarily for the purpose of perfecting existing and acquiring new sports skills, as well as for fun and entertainment, socializing and making new friendships, excitement and challenge, achieving success - winning, gaining physical fitness, competitions, pursuing a career towards a higher level (Bačanac, 2011). This, as well as many other and similar statements, considered in relation to the subject of this paper, which is practical and theoretical models of a long-term athlete development as a function of a new cognitive problem, mean that the child's age, in human development, is a period during which many life experiences and values are acquired through participation in sports. Physical exercise and physical activity enrich child's growth, encourage the development of many attributes and capacities without which, among other things, it is not possible to plan, and thus not to move on to the next step in a sports career (Jevtić and Ropret, 2011). According to the subject of this paper, both theory and practice confirm that success in sport comes through the process of planning long-term development.

Sport theory, in a specific way, addresses the issues of the athlete's development and career, while neglecting the holistic context and meaning of learning about-for-through movement and exercise. In some sense, numerous reductions can be observed in both international and, in particular, domestic sources, for which it can be said they are the result of the studious dealing with children's participation in sports. More intensively than participation, the problems of children's growing up through sport are elaborated, such as insufficient participation or premature termination of sports. In understanding both approaches, but primarily aimed at humanizing childhood growing up through sports, the Faculty of Sports and Physical Education of the University of Belgrade has designed the subject Children's sport, which brings professional and scientific facts of children's growing up through sports under its motto "Children's Sport from Practice to Academic Field". One of the areas in the program of this subject are models of child development through sport. Two decades after the creation of Children's sport as a university subject, and its full academic and practical affirmation, the question of theoretical grounding and practical expediency of the existing models of a longterm athlete development, as a cognitive challenge, are addressed in this paper.

The reasons for such a discussion are the mechanistic takeovers of the offered models of longterm athlete development by many national systems of sports, research and pedagogical institutions. This removed or neglected discussions about the authenticity of the models established on theoretical and practical reductions. According to the definition that sees modelling as a method of cognition as a diminished image of the original, it is obvious that the level of abstraction (simplification) of the real system of a long-time development of an athlete has influenced the validity of the offered models. Therefore, it is convenient to question the success of presenting a structurally, organizationally...complex system of human development through sport, through models. Intense debate is conducted through scientific journals of reference and sports practice documents. Summarizing the extensive theoretical and practical material that is the subject of analysis for the purpose of reaching an answer to the subject and problem of this paper, all suggests that sport theory is not (was not) able to create a framework for a realistic, much less a comprehensive, model of long-term athlete development. In other words, it cannot be said for the theoretical and practical models offered that they do not represent a realistic cognitive and practical system, in terms of both the number and relevance of the factors of the structure and the number of facts that could confirm the authenticity of the original and the model. However, and notwithstanding their cognitive integrity, the models offered, as a context for professional and operational planning, have helped trainers and policy makers in development through sport in their mission to help children and young people to develop through sport, to display and value their talent for sport. On the other hand, an insufficiently productive system of work in sports can encourage children to leave sports, have injuries and spend their talent. Accordingly, the aim of this paper is to propose some important answers in order to move toward a theoretical paradigm for a holistic view of a long-standing level through sport. 


\section{LONG-TERM ATHLETE DEVELOPMENT MODEL - THEORETICAL AND PRACTICAL CONTROVERSY AND/OR A NEW COGNITIVE PARADIGM}

Design and implementation of the long-term athlete development model - DRS is not a new professional step. However, one of the existing models, known by its English acronym -LTAD (Longterm Athlete Development - LTAD), affirmed by Istvan Balyi, seems to dominate this period of development of sport. It was initially set up as a development program for the Canadian Olympic team of alpine skiers. Since its initial draft, it has quickly evolved into a generally accepted development-planning model for young athletes in a wide variety of sports. It has been accepted by a number of other national systems, including Canada, USA, UK, Ireland, Australia, New Zealand and others. In the next steps towards the development of this model, the original context has been redefined and supplemented by the results of the psychologist Andreas Ericsson's research (Ericsson, Krampe \& Tesch-Rome, 1993; Ericsson, 2006, 2008). According to Balyi and Hamilton (Balyi \& Hamilton, 2004) the original model is a 'framework' that is adapted and organized according to the parameters of the child's growth and development. Established on the deductible principles of age (chronological, biological, anatomical, sports) and attributes of growth and development, LTAD is made as a multistage progressive model (6 to 8 levels) depending on the sport branch. The division into levels was in the first step organized around two-year periods of chronological age (of two years' time, from six to 18 years of age), and then continued through periods until the end of the active sports career, that is, through optional periods of lifelong practice in various forms of sport. Subsequent elaborations of the model and its application in other sports, the first stages are summarized into segments of three years of chronological age (6-9, 9-12, 12-15, and 15-18), that is, with continuing one's career at the age of 18 and older. The task of the DRS model is to enable the development of basic motor skills in their optimal phase of physical development, based on the assumption that basic motor skills are adopted and that the young athlete performs the same effectively and economically. Each of the stages of LTAD is clearly defined in terms of motor, cognitive and psychosocial development (Balyi, 2001):

1. Development of basic skills (boys 6-9, girls 5-8 years of age) - the development of abilities and skills through fun and play: $\mathrm{ABC}$ of sport (agility, balance, coordination, speed), RTJ (running, throwing, jumping), KGBS (kinesthetic, gliding, buoyancy, striking with the body) and CPK (catching, passing, kicking)

2. Training study (boys 9-12, girls 8-11 years of age) - the development of abilities through exercises of directed, semi-specific and specific character. The ratio of training and competition is $70: 30 \%$. It is considered the key phase in coordination development.

3. Training abilities (girls 11-14, boys 12-15 years of age) - Individualization of training, adaptation of training to different levels of maturity. The ratio of training and competition is 60:40\%

4. Training for competition (boys 15-18, girls 1417 years of age) - Intensifying the training load. Individualization towards sport, position in the team, competitive discipline. The ratio of training and competition with trainings of competition-specific content is $40: 60 \%$

5. Training for winning (18 plus years of age) Achieving physiological genetic capacity. The ratio of training and competition with trainings of competition-specific content is $25: 75 \%$.

Transition to the next career level involves mastering the previous level program tasks (planning and coaching - learning with outcomes). The aim of each DRS model is to enable the gradual development and attainment of a given level of an athlete without the negative consequences of early specialization, injury and leaving the sport through work appropriate to the age characteristics of a child. One of the objective physiological parameters the basis of which the monitoring, adaptation and evaluation of programs according to the individual characteristics of the individual, i.e. the individualization of the program, is based on the dynamics of growth parameters (peak body height - PBH and peak body mass - PBM). The DRS model, which is operational today but also disputed at the same time, is based on the following postulates (Balyi \& Hamilton, 2004):

- The minimum of 10 years of age or 10,000 hours to achieve the elite athlete level (Bloom, 1985; 
Ericsson et al., 1993; Ericsson \& Charness, 1994);

- Respecting characteristics of "chronological" and "biologic" development. Monitoring body height parameters is used to record children who reach puberty earlier (early puberty) or later (delayed puberty);

- Adapting goals and contents of training to phases of susceptibility of so-called "window of trainability" of a certain system for training stimuli (Canadian sport for life, 2015, p. 32). "Window of trainability" is bordered by periods of determined length and filled with goals of directed motor development. Thus, if a certain period is missed, while contents for the ability development have not been applied, the athlete will not be able to reach his or her maximum potential abilities (Balyi \& Hamilton, 2004);

- Development of basic skills on diversity principles instead of early specialization. The emphasis in LTAD is on the early ability and skill development based on the work of the managing mechanism, i.e. the central nervous system (all forms of coordination and speed, movability and agility) in pre-puberty phases (up to the age of 12 , phases 1 and 2.);

- The number of competitions adapted to the training scope directed towards the technique and basic motor abilities development (large number of competitions in practice also conditions a large scope of competition-specific trainings and not the development of general abilities, or technique in particular);

- Application of the content of training in the form of fun and pleasure;

- Respecting distinctness of the development of boys and girls;

- Affirmation of physical, social and psychological needs of the young,

- Setting in 4 to 8 phases depending on the sport (early or late specialization).

Despite being widely accepted, however, the DRS model has been criticized by a certain number of researchers (Lang \& Light, 2010; Ford, De Ste Croix, Lloyd, Meyers, Moosavi, Oliver, Till \& Williams, 2011; Kiely, 2012; Afonso, 2014; Ackerman, 2014; Côté \& Vierimaa, 2014; Coutinho, Mesquita, Fonseca \& De Martin-Silvaet, 2014; Van Kooten, 2016). Tucker (Tucker, 2013) who affirm that, although the explanation of the model sounds conceptually clear, the DRS has not been fully proven, while Bailey et al. (Bailey, Collins, Ford, MacNamara, Pearce \& Toms, 2010) implicitly claim that the DRS did not go through quality assurance review processes related to academic principles. They state that many of the sources on which Bailey's model is based are difficult to access because many come from the former Soviet Union. Ford et al. (Ford et al., 2011) criticize the DRS model as too one-dimensional, indicating the lack of empirical evidence on which the model is based. These authors suggest, "Interpretations of the model are limited because the data on which they are based rely on questionable assumptions and errors of cognition methods." In addition, they suggest that DRS perceives a generic model, not an individualized athlete development plan.

\section{THEORETICAL REDUCTIONS IN LONG-TERM ATHLETE DEVELOPMENT MODELING}

One of the weaknesses of the Theory of sport derives from its one-sided view of learning in sport. Namely, it is dominated only by motor learning represented through two phases. The first is aimed at forming a general motor base, and the second at training and competitions in a given sports field. Obviously, this reduction in Theory of sport is also found in athlete development models! The same is reflected in a one-sided approach to setting the context of learning about-for-through movement, but also in understanding the fact that sport changes the nature of the child, both in the motor, as well as in the social, cognitive, affective space. It is possible that this reduction in the Theory of sport was deliberate and incurred due to the need for coaches to illuminate only one learning space of a child. The reduction can also be the result of insufficient integrity of the sports sciences and its disciplines. However, Theory of sport can be said to deviate from one of its own principles regarding the non-linear nature of developmental motor skills and capacities that determine success in sport. The epilogue is that sport theory itself does not affirm the importance and share of physical activity, exercise and sport in the development of a child, that it ignores or does not recognize the importance of sensory-motor stimulation in the development of 
abstract thinking, which, along with social learning, affects the intellectual development (conditionally does not recognize Piaget's theory on intellectual development).

Staying within the space of this reduction, it should be emphasized that the goal of the first stage in the child's motor development is to "try out in sports" and to master the skills and habits of the motor, cognitive, social, affective space. The outcome of this phase could be expressed by the outcome of "physical literacy"1), which essentially contains motivation, confidence, physical abilities, knowledge and understanding to evaluate and participate in physical activity (Whitehead, 2013a). Philosophically, the term "physical literacy" encompasses the affective, physical, and cognitive characteristics of human nature, whereby focusing on only one of the characteristics of development would not constitute "physical literacy" (Whitehead, 2013b). On the personal plane of the child, "physical literacy" has value in nurturing and affirming those (personal) abilities and skills that have the potential to enhance and enrich the quality of childhood growth and biopsycho-social maturation without which we would not be able to develop as human beings and act in accordance with our other possibilities (Almond, 2013).

For the analysis of the problem of this paper, it is interesting that the theory of physical education recognizes the acquisition of motor competence, which is positively associated with health benefits, preferences and habits for the lifelong exercise. However, in pursuit of these goals, physical education theory itself relies on and affirms content from selected sports, neglects the motor, methodical and organizational complexity and inappropriateness of the same to a heterogeneous group of students, thus unnecessarily complicating or delaying the process of holistic literacy through this subject. Contrary to the theories mentioned above, the results of scientific research clearly indicate that progress towards the outcomes of the first phase of motor learning, in a human and child-oriented theory of sport, should

\footnotetext{
1) "Physical literacy" represents the pedagogical concept directed towards adoption of basic skills in movement and the basic sports skills that provide a child with self-confidence and control in the wide range of physical activities, rhythmical (dance) and other situations in life. "Physical literacy" involves the ability of recognizing the environment, as well as activities and reactions adequate to situation (Higgs, Balyi, Way, Cardinal, Norris \& Bluechardt, 2008)
}

be established to encourage the development of other aspects of the child development (integral development of a child). Therefore, there is clearly an intra-theoretical and inter-theoretical dissonance, as well as a "crack" in the transfer of the results of research studies into the practice of sports and physical education! Because of the above, it is important to set properly the DRS model and to establish its mission towards "physical literacy" as a pedagogical outcome of participation in sport. From the DRS perspective, "physical literacy" is an outcome that describes the mastery of (motor) knowledge that is undoubtedly a precondition for adopting and effectively performing multipurpose movements that are contained in the specificities of sports fields and disciplines (Kirk \& Rhodes, 2010).

The theory of sport recognizes the first phase of motor development as a period during which a large number of children become involved in mastering the challenges of some of the sports offered, but also as a period in motor development during which a high degree of so-called dropouts is registered. Dropping out of sports due to the actions of factors of different origins, among which there are various forms of abuse registered. In other words, for most children, this phase is also the end of participation in one of the started sports or sports in general, whereby not only questions about the mastery of motor skills are imposed prior to "dropping out of sports" but, above all, motor competence for lifelong learning, exercise and an active lifestyle. Equally important is the answer to the question of mastery of skills, development of abilities, and the acquisition of habits and skills that would facilitate the participation of a child in another sport (the resulting orientation of children's sports in the function of DRS). In support of this are the data from a study conducted by the US Olympic Committee, which indicated that most US Olympians, from the end of the $20^{\text {th }}$ century, participated in a number of sports before the final selection of sports in which they achieved success at the Olympic Games. The ratio of $88: 12 \%$ in male athletes was found in favour of a number of sports or, as stated, $88 \%$ of athletes had tried one of the sports before participating in the main sport. This ratio for girls is $83: 17 \%$. A total of 97\% of OG participants believe that participation in multiple sports was very important for later career success (Gibbons, Hill, McConnell, Forster \& Moore, 2002) 
The conclusion is imposed that sport theory is not clearly profiled in the space of a child's growing up through sport, that it is enclosed in the principles and rules relating to adult sport, that it ignores the attributes, needs and rights of the child to transition through sport on the path of development for life.

\section{PRACTICAL REDUCTIONS IN LONG-TERM ATHLETE DEVELOPMENT MODELING}

By summarizing sports knowledge, defining goals and objectives, content and outcomes of children's growing up and participation in sports, DRS is presented in the professional literature as a model of the development program that takes place through certain stages. The reason for the formation of the DRS model, which is described by stages and periods, from what is called "trial" to "embodiment" and involvement in sport (acquisition phase), through development performance (developmental phase of acquired attributes) leading to top performance in sport (training and competitive perfection) is an attempt to have a comprehensive view of the factors of development of an athlete, as well as to make the development program in a systematic and planned manner. Many researchers have dealt with the problem how to reach a top athlete level, how to maintain that level (an elite athlete) and what the key attributes for achieving success are (Bloom 1985; Lazlo 1986; Stambulova, 1994; Salmela, 1994; Voronzov, 1998; Platonov, 1999; Wyllemand \& Lavallee, 2004). By forming certain theoretical generalizations on this issue, the authors created models based on the principles of developing training careers. Depending on the author, the development from a beginner to a top athlete takes place through a number of stages, starting from the minimum of three phases (initial, development, perfection), through five (preparatory, specialization start, intensive training in the chosen sport, culmination phase, phase of discontinuity in training), up to seven (active start and fun, basics phase; learning about training; competition training; winning training, top level maintenance, lifelong involvement in sports). For some authors, up to 10 stages in the development model can be observed from the beginning to the top result and its maintenance. Regardless of the number of stages in the development model, citation, and authority of the authors themselves, it can be concluded that in all the cited and analysed studies, there are searches for the answer to one of two questions that are dominant, namely the talent of the athlete and the transition of the athlete's career. When this approach is considered in relation to Schlossberg's transition theory (Schlossberg, 1981), then all the above authors can be said to have established the deduced and generalized models of DRS solely on the theory and practice from the space of transition and career, i.e. they were unilateral in their empirical and theoretical work because they neglected the remaining three constituents of Schlozberg's theory (situation, self and support). In other words, it could be accepted that one of the sources of the practical and theoretical reductions of DRS mentioned lies in insufficient interdisciplinary and multidisciplinary recognition and collaboration.

The analysed DRS models, when viewed in their orientation towards achieving results in elite sport, two approaches can be distinguished, one realized through early specialization and dominance of specific training aids, or, the other, which indicates that success arrives through a variety of training methods and tools. The model through early specialization occurs in technically complex sports in which superior performance can be reached even before full physical maturity (sports and rhythmic gymnastics, figure skating, diving). In contrast, the model through a variety of activities and focused play are more common in sports where elite performance is achieved after full maturity (swimming, track and field, martial arts, sports games and others). In this model, specialization occurs between the ages of 13 and 15 , while the specific training and training aimed at achieving maximum abilities is conducted after the age of 16 (Coutinho et al., 2016).

In the context of this discussion, it is important to cite the DRS model that should be established around the concept of "physical literacy" and which is developed as a lifelong value from the age of the new-born (from birth to the age of four); childhood (from five to eleven years of age); adolescence (eleven to eighteen years of age); early adulthood (eighteen to 30 years of age); maturity (30-65 years of age) to older age $(65+)$.

The DRS athlete models are made based on cognitive psychology and theory of motor skills 
learning. Accordingly, there are two approaches to organizing knowledge acquisition (Ericsson, 1993; Côté, Baker \& Abernethy, 2007; Côté, Murphy-Mills \& Abernethy, 2012; Côté, Erickson \& Abernethy, 2013; Ford, Hodges \& Williams, 2013; Moesch, Hauge, Wikman \& Elbe, 2013) through:

- deliberate practice, which represents highly structured activities with clear specific goals toward the development of ability, hard training, low levels of fun and a high level of concentration, dedication, motivation;

- deliberate play that supports intrinsically motivated activities based on the affective aspect of exercise.

The concept of the deliberate practice leads to early specialization, focusing on only one sport and activities that directly mimic the means and methods of elite sport training, and with the expectation that young athletes, early involved in a large amount of specific work, thus build the chances of developing into an elite level athlete. Early guidance and specialization are usually characterized by content without any enjoyment or fun. The consequences of this approach can have a negative effect on motivation, psychological and physical fatigue, injury and giving up further exercise (Baker, 2003; Baker, Cobley \& Fraser-Thomas, 2009; DiFiori, Benjamin, Brenner \& Gregory, 2014).

The concept of the deliberate play is based on the diversity in the application of motor content characterized by activities with an emphasis on entertainment. It is applied in the early stages of sports development. Research by Hayman et al. (Hayman, Polman, Taylor, Hemmings \& Borkoles, 2011; Hayman, Borkoles, Taylor, Hemmings \& Polman, 2014), Kutinja et al. (Coutinho et al., 2014), Baker et al., (Baker, Côté \& Deakin, 2005) and Memmert with trainings of competition-specific content is (Memmert, Baker \& Bertsch, 2010) indicate that athletes who are involved in a variety of motor activities (the deliberate play) in a timely manner can reach the elite athlete level. Timely participation in a variety of sports activities enables young people to acquire a variety of physical, cognitive, affective and psychological skills and abilities that can have a positive transfer to a later athlete's specialization (Baker, Côté \& Abernethy, 2003; Côté, Lidor \& Hackfort, 2009). The above concept makes it unclear whether, and how, the transfer of learned skills to other life activities occurs!
The model analysis indicates that few authors have provided a comprehensive cognitive model of DRS, which would be established around the facts that a given concept can be applied to in a given sport. There are also no clear parameters the basis of which the assessment of progress and progress itself can be evaluated on the attribute scale and the scale of sports competence. As a result, early specialization is often misinterpreted and equalled to the deliberate practice while early diversity is equalled to the deliberate play. In theory, these concepts are clearly demarcated and may be in interaction (coexistence).

Development athlete models have achieved their application through various forms of the planned development of an athlete, from beginner to elite result. Based on the analysis of a number of papers (Bloom, 1985; Salmela, 1994; Stambulov, 1994; Côté, 1999; Wylleman \& Lavallee, 2004; Abbott \& Collins, 2004; Bailey \& Morley, 2006; Bruner, Erickson, Wilson \& Côté, 2010), we have identified two main concepts that can be presented as two sub models, namely one concerning the development of talent and transition of talents. The talent development sub-model is a multistage, progressive construct that describes changes in the development of athletes. Bailey and Morley (2006) state that the same must be a multidimensional form that incorporates influences of interpersonal, intrapersonal, cognitive and creative abilities. The same authors cite the lack of information relating to the quantification of the components of each phase as a weakness, and that many components are difficult or almost impossible to test.

\section{CONCEPTUAL MODELS OF LONG-TERM ATHLETE DEVELOPMENT}

Conceptual models emerge because of recognition of a clear structure, logic of functioning of a practical and theoretical system. They are also structural models because they indicate the structure of the system and, as such, are adapted as a means of communication within the profession. Recent significant conceptual models of athlete development cited in the literature are the following: 
1. Model phase Foundation, Talent, Elite, Mastery - FTEM - (Gulbin, Croser, Morley \& Weissensteiner, 2013),

2. Development Model of Sport Participation, DMSP - (Côté, Baker \& Abernethy, 2003 i 2007),

3. Career Transition Model CTM - (Stambulova, 1994; Willeman \& Lavallee, 2004),

4. Long-term Athlete Development- LTAD (Balyi, 2001).

FTEM model contains 10 clearly differentiated levels. The disadvantage of this model is that it does not sufficiently appreciate the processes, especially in young people who are late in their pubertal development (Gulbin, Croser, Morley \& Weissensteiner, 2013).

The DMSP model strives to clearly define constraints in the development of an athlete. The model follows three forms of sport participation: (1) recreational sport participation through early diversity in sports choice and deliberate play, (2) development of superior skills through early participation in a variety of activities and deliberate play, and (3) development of superior skills through early specialization and deliberate practice. The quality of this model is the clear identification of indicators for each level that are consistent with the theories of development of children and young people (Coutinho et al., 2014).

The CTM model, unlike the previous ones, clearly links the cause-and-effect relationships in processes, influence on outcomes, as well as key elements in five-level transition processes.

For these concepts and models of athlete development, the greatest challenge for researchers is to determine the criteria that define an elite athlete, his or her development, the degree of his / her achievement, and the characteristics that need to be developed and monitored. By clearly defining these parameters, different interpretations and problems in comparison would be avoided.

\section{Theoretical and practical speculations on truthfulness of the LTAD principle}

Challenges to the reality of the LTAD program functioning are the most numerous in the area of lack of scientific research and evidence based on longitudinal studies that would confirm statements about periods of susceptibility and their association with age. The aforementioned disadvantages limit the validity of LTAD. Claims about psychological and social characteristics at particular ages and their association with success in sport are based on theoretical considerations without concrete evidence (Tucker, 2013). Bailey et al. (2010) indicated that the conclusions about the periods of susceptibility ("windows") were empirical and that there was no exact, solid, experimental evidence. The authors of the model, Balyi and Hamilton (Balyi \& Hamilton, 2004) personally confirmed that their work is the result of empirical observations. Much earlier, Beunen and Malina (Beunen \& Malina, 1996) pointed to evident variations in the development of motor skills depending on the degree of growth and development, but there was clearly no clarity on the role of the type and level of stimuli on their changes. Claims that susceptibility periods have a definite duration (beginning and end) and that missed stages are irreplaceable are also questionable because the successes of those who were later engaged in sports speak against such attitudes (Viru, Loko, Harro, Volver, Laaneots \& Viru, 1999; Van Kooten, 2016). The relevance of these views is confirmed by the results of a survey of 1720 US Olympians who show that the average age at entry into sport is 11.4 years (Riewald, 2014)

The lack of acceptable methods of quantifying training, paediatric data, the breadth of applied stimuli for a very wide range of different sports hinders the ability to accurately investigate the effect of stimuli for the developmental of abilities, and in connection with the degree of growth and development (Ford et al., 2011).

The results of certain studies on these issues are contradictory. One speaks of the "skill barrier", that is, progress in development toward specialization and specific skills depends on basic motor patterns developed at an early age (Gallahue \& Ozmun, 1998; Gallahue \& Donnelly, 2003). Second, they do not support views on the conditionality of developmental ability and the degree of growth and development.

From a neurological point of view, research indicates that brain mass reaches its peak development in infancy (Rabinowicz, 1986) and that periods from 6-8 and 10-12 years of age coincide with periods of development of motor skills (Higgs, Balyi, Way, Cardinal, Norris \& Bluechardt, 2008; Cratty, 1986). However, it is evident that these are development periods, but without concrete evidence 
that this represents a period of greater sensitivity and susceptibility to training stimuli.

Studies on the relationship between aerobic endurance development and susceptibility periods (Jones \& Carter, 2000; Williams, Armstrong \& Powell, 2000; Mahon, 2008; Rowland, 1997; Viru, 1999) have not demonstrated a direct relationship between aerobic endurance development and susceptibility periods. Most indicators of aerobic endurance development are related to body size, mass development and body composition.

The periods of susceptibility to velocity development have also remained without concrete evidence despite numerous studies (Beunen \& Malina, 1996; Viru, 1999; Whithall, 2003; Butterfield, Lehnhard, Lee \& Coladarci, 2004). Changes in velocity have been found to occur but are related to biological, neural and biomechanical factors that can be associated with both age and maturation.

The problem of the objective existence of susceptibility stages for the development of strength has been addressed by several researchers (Pfeiffer \& Francis, 1986; Vrijens, 1978; Lillegard, Brown, Wilson, Henderson \& Lewis, 1997), of which only one paper (Vrijens, 1978) has indicated a significant increase strength in the post-puberty period (16.8 years of age) compared to the pre-puberty period (10.5 years of age).

Measurements of muscular strength indicated that training has the effect of improving strength by increasing muscle mass and muscle synchronization (Beunen \& Malina, 1988), but without evidence of association of development with age. The conclusion of Ford et al. (Ford et al., 2011) is that the assumptions on which LTAD is based upon are speculative and unfortunately without any empirical evidence.

\section{Challenges for verification and validation of the concept of ten thousand hours of training}

One of the first postulates of LTAD is that 10,000 hours of sports training, or 10 years ( 20 hours a week) are required to succeed in sports and to reach the elite level. The rule emerged from a study by Ericsson et al. (1993) on the association between the success of violin students at the Berlin Academy and the average volume of 10,000 hours of practice up to the age of 20 . Research in the field of sports (Bloom, 1985; Ericsson \& Charness, 1994) has indicated that it takes 8 to 12 years to train talented athletes to reach the elite athlete level. Data from the US Olympic Committee points out that it takes 13 years of training to get results on the level of participation in the Olympic team, and 15 years to win the Olympic medal. The 10,000-hour coaching rule has become widely accepted in almost all models and variations of the LTAD model. Criticism of the 10,000-hour postulate referred to insufficient scientific and experimental evidence of the data, and that this volume of work did not necessarily lead to the elite level in sports. Ericsson and Pool (Ericcsson \& Pool, 2016) explained the criticism expressed, pointing out that a survey conducted on violin students in 1993, who are still not elite musicians but only successful students, and that elite musicians are in their 30s and with 20-25,000 hours of exercise; that these are average results; that it is not about any exercise but high intensity work with high motivation and concentration; that anyone who trains 10,000 hours is not expected to reach the level of an elite athlete, and that the assumption about the greater importance of deliberate training of 10,000 hours in relation to genetic predispositions is wrong. According to Erikson, the 10,000 hours rule was misinterpreted, it was not related to sports skills, and, in that sense, was not scientifically proven. It was accepted because it "seemed magical, respectable, with a round figure" (Ericcsson \& Pool, 2016).

Studies by a number of researchers (Helsen, Starkes \& Hodges, 1998; Baker et al., 2003; Soberlack \& Côté, 2003; Berry, Abernethy \& Côté, 2008) have indicated that athletes reach the elite technique level earlier, after 4000-6000 hours of specific exercise.

According to Tucker (Tucker, 2013), a significant drawback of the LTAD model is that it does not take into account those who are delayed in development, so that the 10,000-hour principle is unrealistic.

\section{Learning technique through large scope and low intensity}

One of the LTAD model postulates is to focus on the development of techniques and general motor skills in the first stages (9-12 and 12-15 years of age), i.e. "physical literacy" instead of competitive results. Practice has shown that a coach focusing on the result causes an increase in the intensity of training, which results in neglect of technique, and higher intensity leads to an increased possibility of injury, overtraining, "mental burnout", giving up (Lang \& Light, 2010). 
Unfortunately, misinterpretation of LTAD recommendations that volume and not the intensity of training load is important at an early age has led to the development of inappropriate work programs and recommendations. Guided by the emphasis on volume rather than training intensity, the ASA (Amateur Swimming Association - UK) recommended coaches that athletes should, in the second phase of the program (9-12 years of age), swim about 8000 meters per week. Coaches, concentrating on this task as and due to lack of training time, neglected practicing technique (Moore, Collins \& Burwitz, 1998; ASA, 2003).

Multiple researchers indicate that the misapplication of high-volume training has the effect of reducing the volume of technique training and neglecting the fact that the basic technique is taught at lower movement speeds (Greyson, Kelly, Peyrebrune \& Furniss, 2010); increase the risk of injury due to overload (Abbott, Collins, Martindale \& Sowerby, 2002), physical and mental fatigue and burnout (Hollander, Meyers \& LeUnes, 1995); giving up by those incapable of following such workload (Salguero, Gonzalez-Boto, Tuero \& Marquez, 2003) as well as the problem of including athletes who take up swimming later (Abbott et al., 2002). As an additional criticism of this mode of work, Faude et al. (Faude, Meyer, Scharhag, Weins, Urhausen \& Kindermann, 2008) state that a high volume of low intensity training, aimed at the development of aerobic abilities, has little effect on activities lasting from 20 seconds to 5 minutes. Most competitive disciplines (80\%) in swimming do not last more than 5 minutes and call into question the usefulness of this type of training.

According to research by Lang and Light (Lang \& Light, 2010), coaches believe that the LTAD guideline for building swimmers through long-distance training can impede the development of athletes talented for shorter disciplines. Researchers agree that in order to advance in development, the quality of exercise is more important than the quantity of work (Ford, Yates \& Williams, 2010; Low, Williams, McRobert \& Ford, 2013; Côté, Erickson \& Abernethy, 2013; Baker \& Young, 2014), that technique is the key to future sporting excellence and a prerequisite for the subsequent development of specific skills (Gallahue, 1982; Moore et al.,1998; Schmidt \& Wrisberg, 2004; Bloom, 1985; Van Rossum, 2001).

Comparing the training volume of the different systems (UK and Australia) indicates that there are no significant differences; the Australian model is with a larger range of scopes: for the first phase, it envisages a weekly range of $6-17.5 \mathrm{~km}$ and a British 8 - $16 \mathrm{~km}$ per week. For the second phase, the volumes are partly different, the Australian recommends 14$36 \mathrm{~km}$ and the British 24-32 km (Lang \& Light, 2010). The authors conclude that it is probably a mistake either that the trainers apply too much volume or that they did not integrate the technique exercises into the training.

\section{The relationship of training and competition}

The criticisms of the LTAD model implementation also apply to the extent of competition, discipline and age of competitors. One example is the British Swimming Association (ASA) program. Bill Sweetenham, Director of the British Swimming Federation, criticized national programs based on the LTAD model for the large number of competitions (12) and the inadequate number of training sessions (Affolter, 2016). The ASA lowered the minimum age for state competitions to 10 years of age for girls and 11 for boys, excluded races at 50 and $100 \mathrm{~m}$ from the program, and introduced $200 \mathrm{~m}$ race. Subsequently, disciplines $800 \mathrm{~m}$ and $1500 \mathrm{~m}$ were introduced for girls of 11 and boys of 12 years of age. The reason for these changes is "the lack of physical development required to swim properly in a sprint" (Grange \& Gordon, 2004). According to some authors (Brandon, 2002; Maglischo, 2003) competitions in $200 \mathrm{~m}$ sections are more stressful than in the case of sprints in shorter sections.

In the analysis of the Judo Canada NCCP Committee, Van Kooten (2016) presents the inconsistencies of the Judo LTAD program: $88 \%$ of Olympic and world medal winners started this sport at the age of 11 , which means they "skipped" phase 2 (the most important one) of the program. The program prescribes that those younger than 12 years of age should avoid "specialization", "negative competitive experiences", "being compared to other children", and well as all activities should be in the "form of play and fun". Therefore, it is surprising to find the recommendation of the program that the A7 and A9 children should learn specific throwing techniques as well as pass competitions on the club level. 


\section{Other postulates of LTAD exposed to critics}

Coaches and parents are an indispensable factor in implementing the LTAD model. Black and Holt (Black \& Holt, 2009), as well as Lang and Light (Lang \& Light, 2010), have found that the LTAD program provides a national framework for structuring talent development systems. However, one cannot speak of wider acceptance and implementation of the LTAD principle, except as a general strategy. Banack et al. (Banack, Bloom \& Falcao, 2012) indicate that, in addition to considering the positive aspect that everyone "speaks the same language", less experienced young coaches and parents of beginners have positive attitudes towards LTAD, while more experienced coaches have some reservations about the model and that largely adhere to personal experience. Coaches who work with younger children up to 9 years of age (basic phase) agree with the program principles, while older coaches show the aforementioned reservations towards the model.

In addition, the problem of fulfilling the principles of sports development is the imperative of the environment for coaches to achieve results from an early age, which causes children who are delayed in development to be neglected in the process of training and selection. Black and Holt (Black \& Holt, 2009) find that coaches do not accept the LTAD model due to lack of information and education on its implementation. Insufficient education and training of coaches are shown in ignorance of the principles of selection, selection of tests and criteria that, if any, are different from club to club and beyond. A significant drawback was the linkage between the systems at the club, regional and national levels.

In realizing the principle that success in (pre) adolescence is not the primary task, the problem arises that many coaches are guided by the traditional approach that success (a medal) at an early age is the only measure and evidence of talent. For this approach, justification is found in the sports culture tradition of most nations (Lang, 2009; Abbott et al., 2002) and in the previous, personal experience from most coaches (Gould, Gianinni, Krane \& Hodge, 1990; Gilbert \& Trudel, 2001; Cushion, Armor \& Jones, 2003; Black \& Holt, 2009).

It is obvious that the implementation of LTAD is influenced by poor education of trainers and poor knowledge in the field of importance for quality work. Rowley (1994) points out that $85 \%$ of football coaches do not use any research tools to identify talent. Coaches should be educated on how to use the data required by LTAD model.

\section{CONCLUSION}

I The analysis of the current long-term athlete development models shows that, in spite of the progress in knowledge, the theory and practice display significant differences in approach to this problem. The lack of longitudinal research, insufficiently elaborated system of monitoring, control and evaluation of an athlete influences the credibility of the offered long-term development models. One of them, LTAD, was created as the leading guideline in the development of an individual in accordance with his/her biological, motoric, cognitive and psychosocial characteristics.

II Despite its widespread implementation, however, little is known about the effects of applying the LTAD model in the context of an individual case. From the moment of its implementation to date, approaches have been identified which affirm but also challenge it. A large number of determinants, primarily individual dynamics and non-linearity of the bio motor development of the child-athlete, require a longitudinal approach to knowledge in relation to the practice of exploring time-dependent series of assessment of individual abilities. In other words, it is necessary to create a cognitive system that would verify individual and inter-individual differences in adaptations of the trained attributes of the athlete within the specificity of a given sport branch. The lack of theoretical and practical context of individual sports branches is imposed as a limiting factor in the verification of the theoretical and practical importance of LTAD.

III The broader programmatic context of LTAD has been formed under the constant analysis of experts in various fields of science dealing with childhood growing up, who, chronically, raise questions of scientific veracity and the practical applicability of the model, and within it: 
- Terms and then stages of susceptibility in motor development of the child-athlete. Research has shown no relevant evidence of this stage, while some studies have also challenged their credibility;

- Claims on the amount of training required to reach the level of an elite athlete. They have been challenged for applying an inadequate methodology, suspicion of speculation in conclusions that athletes with less workload reach the desired level;

- Recommendation on the advantage of the training load versus intensity. Misunderstandings about specificity of certain motor abilities are evident.

IV The perceived shortcomings of this and other DRS models stem from the inadequacy in operational planning of the implementation that arises and due to the (absence of) knowledge of the coach about the characteristics of the development of a child, working methods, principles and methods of selection, and thus did not offer an orientation of practice in: (1) work with children who later enter the puberty phase later, (2) work with children who enter the sport at a later age;

$\checkmark$ The LTAD model is always asked questions such as

a) What are the factors that, in the listed circumstances, make it possible to acquire basic skills and habits from the motor, cognitive, social, and affective space ("physical literacy") and which are key to further progress?

\section{REFERENCES}

1. Abbott, A. \& Collins, D. (2002). A theoretical and empirical analysis of a "State of art" talent identification. High Ability Studies, 13(2) 157-178

2. Abbott, A.\& Collins, D. (2004). Eliminating the dichotomy between theory and practice in talent identification and development: considering the role of psychology. J Sports Sci, 22: 395-408. b) Whether the individual's talent, influence of another sport or daily physical activity in the environment ("family sport", "backyard sport") affect "physical literacy" and creation of the performance relevant to continuation of a career and potential success in elite sport.

VI With a comprehensive analysis of the context of LTAD and other DRS models, it is noted that their starting point must be established around the concept of "physical literacy".

VII There are various theoretical and practical approaches around "physical literacy" to determine its being, significance and modality of development. What is concrete refers to the non-formal course of its acquisition during which children gain the first high-quality skills, abilities, habits, develop character, affirm their talent. In contrast, there are modalities of directional activity carried out in physical education and sports clubs (formal system). The non-formal belongs to the unique process of acquiring "physical literacy" as the outcome of a development phase after which the following phases are planned (acquisition, development of specific attributes, training and competitive magnificence) within one of the DRS models.

VIII The truthfulness of the DRS model is still in the process of theoretical and practical verification. The discussion offered is a framework for new strides in the approach to comprehensive theory and practice of children's and youth sports.

3. Abbott, A., Collins, D., Martindale, R. \& Sowerby, K. (2002). Talent Identification and Development: An Academic Review, Sportscotland, Edinburgh.

4. Ackerman, P.L. (2014). Nonsense, common sense, and the science of expert performance: Talent and individual differences. Intelligence, 45, 6-17.

5. Afonso, J. (2014). Long-term athlete development model - A critique. Dostupno 5.9.2019 na: http:// 
www.youtube.com/watch?v=VVwPXcCWr8o\&fe ature $=$ youtu.be

6. Affolter, F. (2016) Critical Analysis of LTAD model. dostupno 5.9.2019 na https://www.researchgate.net/publication/316513256_Critical_Analysis_of_LTAD_model .

7. Almod, L. (2013). What is the Value of Physical Literacy and why is Physical Literacy valuable? ICSSPE Buelletin“Physical Literacy”, 65: 35-42.

8. Amateur Swimming Association (ASA) (2003). The Swimmer Pathway: Long Term Athlete Development, ASA, Loughborough.

9. Bačanac, LJ., Petrović, N., i Manojlović, N. (2011). Psihološke osnove treniranja mladih sportista. [Psychological bases of young athletes coaching. In Serbian.] Beograd: Republički zavod za sport.

10. Bailey, R.\& Morley, D. (2006). Towards a model of talent development in physical education. Sport Educ Soc, 11: 211-230.

11. Bailey, R.P., Collins, D., Ford P.A., MacNamara, A., Pearce, G.\&Toms, M. (2010). Participant development in sport: An academic literature review. Commissioned report for Sports Coach UK. Leeds: Sport Coach UK.

12. Baker, J., Cobley, S, \& Fraser-Thomas, J. (2009) What do We Know about Early Sport Specialization? Not Much! High Abil Stud, 20: 77-89.

13. Baker, J.\& Young, B. (2014). 20 years later: deliberate practice and the development of expertise in sport. Int Rev Sport Exerc Psychol,7: 135-157.

14. Baker, J., Côté, J.\& Abernethy, B. (2003). Learning from the experts: practice activities of expert decision makers in sport. Res Q Exerc Sport, 74: 342-347.

15. Baker, J., Côté, J.\& Abernethy, B. (2003). Sportspecific practice and the development of expert decision-making in team ball sports. J Appl Sport Psychol, 15: 12-25.

16. Baker, J., Côté, J.\& Deakin, J. (2005). Expertise in ultra-endurance triathletes early sport involvement, training structure, and the theory of deliberate practice. J Appl Sport Psychol, 17: 64-78.

17. Baker, J. (2003). Early specialization in youth sport: a requirement for adult expertise? High Abil Stud, 14: 85-94.

18. Balyi, I. (2001).Sport system building and Longterm athlete development in British Columbia. Canada: Sport Med BC
19. Balyi, I. \& Hamilton, A. (2004).Long-Term Athlete Development: Trainability in Childhood and Adolescence. Windows of Opportunity. Optimal Trainability, National Coaching Institute British Columbia \& Advanced Training and Performance Ltd, Victoria, BC.

20. Banack, H., Bloom, G. \& Falcao W. (2012). Promoting long term athlete development in cross country skiing throught competency-based coach education: A quantitive study.International Journal of sport science and coaching. Vol 7 (2), 301-312

21. Berry, J., Abernethy, B.\&Côté, J. (2008). The contribution of structured activity and deliberate play to the development of expert perceptual and decision-making skill. J Sport Exerc Psychol, 30: 685-708.

22. Beunen, G., \& Malina, R. M. (1996). Growth and biological maturation: Relevance to athletic performance. In O. Bar-Or (Ed.), The child and adolescent athlete (pp. 3-24). Oxford: Blackwell.

23. Black, D.E. \& Holt, N.L. (2009). Athlete Development in Ski Racing: Perceptions of Coaches and Parents.International Journal of Sports Science \& Coaching, 4(2), 245-260.

24. Bloom, B.S., (1985). Developing Talent in Young People. New York: Ballantine.

25. Brandon, R. (2002). Why High-Intensity Training is a Better Model Than High-Volume Training for Swimmers, Especially Sprinters, Peak Performance, 167, 8-14.

26. Bruner, M., Erickson, K., Wilson, B. \& Côté, J. (2010). An appraisal of athlete development models through citation network analysis. Psychol Sport Exerc. 11: 133-139.

27. Butterfield, SA., Lehnhard, R., Lee, J.\& Coladarci, T. (2004). Growth rates in running speed and vertical jumping by boys and girls ages 11-13. Perceptual and Motor Skills, 99, 225-234.

28. Canadian Sport for Life (2015) dostupno 15.9.2019 na: www.canadiansportforlife.ca

29. Côté, J.\& Vierimaa, M. (2014). The developmental model of sport participation: 15 years after its first conceptualization. Science \& Sports, 29(S), S63-S69.

30. Côté, J., Baker, J.\& Abernethy, B. (2003). From play to practice: a developmental framework for the acquisition of expertise in team sport. In: Starkes J \& Ericsson KA (eds) Expert performance 
in sports: advances in research on sport expertise. Champaign: Humam Kinetics, pp.89-113.

31. Côté, J., Baker, J.\& Abernethy, B. (2007). Practice and play in the development of sport expertise. In: Eklund $R$ \& Tenenbaum $G$ (eds) Handbook of sport psychology. Hoboken: Wiley, pp.184-202.

32. Côté, J., Erickson, K.\& Abernethy, B. (2013). Play and practice during childhood. In: Côté' J \& Lidor $R$ (eds) Conditions of children's talent development in sport. Morgantown: FIT, pp.9-20.

33. Côté, J., Lidor, R.\& Hackfort, D. (2009). ISSP position stand: to sample or to specialize? seven postulates about youth sport activities that lead to continued participation and elite performance. Int J Sport Exerc Psychol, 9: 7-17.

34. Côté,J., Murphy-Mills, J.\& Abernethy, B. (2012). The development of skill in sport. In: Hodges $N$ \& Williams AM (eds) Skill acquisition in sport: research, theory and practice. New York, NY: Routledge,pp.269-286.

35. Côté J. (1999). The influence of the family in the development of talent in sport. Sport Psychol, 13: 395-417.

36. Coutinho, P., Mesquita, I., Fonseca, AM.\&De Martin-Silvaet, L. (2014). Patterns of sport participation in portuguese volleyball players according to expertise level and gender. Int J Sport Sci Coach, 9: 579-592.

37. Cratty, B.J. (1986). Perceptual motor development in infants and children (3rd edn.). Englewood Cliffs, NJ: Prentice-Hall.

38. Cushion, C.J., Armour, K.M. \& Jones, R.L. (2003). Coach Education and Continuing Professional Development: Experience and Learning to Coach, Quest, 55, 215-230.

39. DiFiori, JP., Benjamin, HJ., Brenner, J.S.\& Gregory, A. (2014). Overuse injuries and burnout in youth sports: a position statement from the American medical society for sports medicine. $\mathrm{Br}$ J Sports Med, 48: 287-288.

40. Ericsson, K.A. (2006). Cambridge handbook of expertise and expert performance. New York: Cambridge University

41. Ericsson, K.A. (2008). Deliberate practice and acquisition of expert performance: A general overview. Academic Emergency Medicine, 15(11), 988

42. Ericsson, K.A, \& Charness, N. (1994). Expert performance: its structure and acquisition. Am. Psy- chologist, 49(8), 725-747

43. Ericsson, KA., Krampe, R.\& Tesch-Rome,C. (1993). The role of deliberate practice in the acquisition of expert performance. Psychol Rev; 100: 363-406.

44. Ericsson, A. \&Pool, R. (2016) Peak: Secrets from the New Science of Expertise. Houghton Mifflin Harcourt

45. Faude, O., Meyer, T., Scharhag, J., Weins, F. Urhausen, A. \& Kindermann, W. (2008). Volume vs. Intensity in the Training of Competitive Swimmers.International Journal of Sports Medicine, 29, 906-912.

46. Ford, P., Hodges, N.\& Williams, AM. (2013). Creating champions: the development of expertise in sport. In: Kaufman SB (ed.) The complexity of greatness: beyond talent or practice. New York, NY: Oxford University Press, pp.391-412.

47. Ford, P., Yates, I.\& Williams, AM. (2010). An analysis of practice activities and instructional behaviours used by youth soccer coaches during practice: exploring the link between science and application. J Sports Sci, 28: 483-495.

48. Ford, P., De Ste Croix, M., Lloyd, R., Meyers, R., Moosavi, M., Oliver, J., Till, K. \& Williams C. (2011). The Long Term Athlete Development model: Physiological evidence and application. Journal of sport Science, Feb. 15th; 29(4): 389-402

49. Gallahue, D.L. (1982).Fundamental Movement Experiences for Children, New York: Wiley.

50. Gallahue, D. \& Donnelly, F. (2003). Development of physical education for all children ( $4^{\text {th }}$ edn.) Champaign, Il: Human Kinetics

51. Gallahue, D.L. \& Ozmun, J.C. (1998). Understanding motor development. New York. Mc Graw-Hill.

52. Gibbons, T., Hill, R., McConnell, A., Forster, T., \& Moore, J. (2002). The path to excellence: A comprehensive view of development of U.S. Olympians who competed from 1984-1998. United States Olympic Committee

53. Gilbert, W. \& Trudel, P. (2001). Learning to Coach Through Experience: Reflection in Model Youth Sport Coaches.Journal of Teaching and Physical Education, 21, 16-34.

54. Gould, D., Gianinni, J., Krane, V. \& Hodge, K. (1990). The Educational Needs of Elite U.S. National Pan American and Olympic Coaches.Journal of Teaching in Physical Education, 9, 332-344. 
55. Grange, J. \& Gordon, R. (2004). Success is Long Term: Long Term Athlete Development Related to the Journey Through Swimming, ASA, Loughborough.

56. Greyson, I., Kelly, S., Peyrebrune, M., \& Furniss, B. (2010). Research Notes: Interpreting and Implementing the Long Term Athlete Development Model: English Swimming Coaches' Views on the (Swimming) LTAD in Practice: A Commentary. International Journal Of Sports Science \& Coaching, 5(3), 403-406.

57. Gulbin, J., Croser, M.J., Morley, E.J. \&Weissensteiner JR. (2013). An integrated framework for the optimisation of sport and athlete development: a practitioner approach. J Sports Sci, 31: 1319-1331.

58. Hayman, R., Borkoles, E., Taylor, J.A., Hemmings, B.\& Polman, R. (2014). From pre-elite to elite: the pathway travelled by adolescent golfers. Int J Sports Sci Coach, 9: 959-974.

59. Hayman, R., Polman, R., Taylor, J., Hemmings, B. \& Borkoles, E. (2011). Development of elite adolescent golfers. Talent Dev Excell, 3: 249-261.

60. Helsen, W.F., Starkes, J.\& Hodges, N. (1998). Team sports and the theory of deliberate practice. J Sport Exerc Psychol, 20: 12-34.

61. Higgs, C., Balyi, I., Way, R., Cardinal, C., Norris, S.\& Bluechardt, M. (2008). Developing physical literacy: A guide for parents of children ages 0 to 12 . A supplement to Canada Sport for Life. Vancouver, British Columbia: Canadian Sport Centres

62. Hollander, E.B., Meyers, M.C. \& LeUnes, A. (1995). Psychological Factors Associated with Over-Training: Implications for Youth Sport Coaches, Journal of Sport Behaviour, 18, 3-20.

63. Jevtić, B. i Ropret, R. (2011). Dugoročno planiranje sportske karijere. [Long-term sports career planning- In Serbian]. U: Jevtić B, Radojević J., Juhas I., Ropret $R$ (ed) Children's sports, from practice to academic discipline. Beograd: Fakultet sporta i fizičkog vaspitanja, str 281-297

64. Jones, A.M.\& Carter, H. (2000). The effect of endurance training on parameters of aerobic fitness. Sports Medicine, 29, 373-386.

65. Kiely, J. (2012). Periodization paradigms in the 21st century: Evidence-led or tradition-driven? International Journal of Sports Physiology and Performance, 7, 242-250.
66. Kirk, M.A\& Rhodes, R.E. (2010). Occupation correlates of adults' participation in leisure-time physical activity: a systematic review.Am J Prev Med, Apr;40(4):476-85

67. Lang, M., (2009). Swimming in the Panopticon: An Ethnographic Study of Good Practice in Competitive Youth Swimming, PhD Thesis, Leeds Metropolitan University.

68. Lang, M. \& Light, R. (2010). Interpreting and Implementing a Long Term Athlete Development Model: English Swimming Coaches' Views on the (Swimming) LTAD in Practice, International Journal of Sports Science and Coaching, 5, 389-402.

69. Lazlo, N. (1986). Il tempo di costuire. Rivista di cultura sportiva. SDS, 3-4, 6-10.

70. Lillegard, W.A., Brown, E.W., Wilson, D.J., Henderson, R.\& Lewis, E. (1997). Efficacy of strength training in prepubescent males and females: Effects of gender and maturity. Paediatric Rehabilitation, 1, 147-157.

71. Low, J., Williams, A.M., McRobert A. \& Ford, P. (2013). The microstructure of practice activities engaged in by elite and recreational youth cricket players. J Sports Sci, 31: 1242-1250.

72. Maglischo, EW. (2003).Swimming Fastest: The Essential Reference on Technique, Training and Program Design, Human Kinetics, Champaign, IL.

73. Mahon, A.D. (2008). Aerobic training. In N. Armstrong \& W. Van Mechlen (Eds.), Paediatric exercise science and medicine (pp. 273-286). Oxford: Oxford University Press.

74. Martindale, R.J., Collins, D. \& Abraham, A. (2007). Effective Talent Development: The Elite Coach Perspective in UK Sport.Journal of Applied Sport Psychology, 19,187-206.

75. Memmert, D., Baker, J.\& Bertsch, C. (2010). Play and practice in the development of sport-specific creativity in team ball sports. High Abil Stud, 21: 3-18.

76. Moesch, K., Hauge, M.T., Wikman J.M.\& Elbe, M. (2013). Making it to the top in team sports: start later, intensify, and be determined! Talent Dev Excell, 5: 85-100.

77. Moore, P.M., Collins, D. \& Burwitz, L. (1998).The Development of Sporting Talent 1997: An Examination of the Current Practices for Talent Development in English Sport. London: English Sports Council. 
78. Pfeiffer, R., \& Francis, R. (1986). Effects of strength training on muscle development in prepubescent, pubescent and postpubescent males. Physician and Sportsmedicine, 14, 134-143.

79. Platonov, N.V. (1999). La concezione della"periodizzazione" e lo sviluppo di una teoria dell allenamento. Rivista di cultura sportiva. SDS. XVIII(45), 3-7.

80. Rabinowicz, T. (1986). The differentiated maturation of the cerebral cortex. In F. Falkner \& J. Tanner (Eds.), Human growth: A comprehensive treatise, Vol. 2. Postnatal growth: Neurobiology (2nd edn., pp. 385-410). New York: Plenum.

81. Riewald, S. (2014). The Path to Excellence: A View on the Athletic Development of U.S. Olympians Who Competed from 2000-2012. USA Olimpic Committee.

82. Rowland, T.W. (1997). The "trigger hypothesis" for aerobic trainability a 14 -year follow-up (editorial). Pediatric Exercise Science, 9, 1-9.

83. Rowley, S. (1994). The British perspective: talent identification and selection - the future for British Governing Bodies. BOA CAG Seminar: London.

84. Salguero, A., Gonzalez-Boto, R., Tuero, C. \& Marquez, S. (2003). Identification of Dropout Reasons in Young Competitive Swimmers, Journal of Sports Medicine and Physical Fitness, 43(4), 530534.

85. Salmela, J. (1994). Stages and transitions across sports careers. In: Hackfort D (ed.) Psycho-social issues and interventions in elite sports. Frankfurt: Lang, pp.11-28.

86. Schmidt, R. \& Wrisberg, C. (2004).Motor Learning and Performance: A Problem-Based Learning Approach, Human Kinetics, Champaign, IL., 2004.

87. Schlossberg, N.K. (1981). A model for analyzing human adaptation to transition. The Counseling Psychologist, 9, 218

88. Soberlack, P.\&Côté, J. (2003). The developmental activities of elite ice hockey players. J Appl Sport Psychol, 15: 41-49.

89. Stambulova, N. (1994). Developmental sports career investigations in Russia: a post-perestroika analysis. Sport Psychol, 8: 221-237.

90. Tucker, R. (2013) Long term athlete development - Teh science of sport dostupno 15.9.2019 na https://sportsscientists.com/2013/02/long-termathlete-development-foundations-challenges
91. Van Kooten, C. (2016). Re-consideration LTAD on coach education: An illustration from judo. International Sport Coaching Journal, (3), 83-89

92. Van Rossum, J.H. (2001). Talented in Dance: The Bloom Stage Model Revisited in the Personal Histories of Dance Students, High Ability Studies, 12, 181-197.24

93. Viru, A., Loko, J., Harro, M., Volver, A., Laaneots, L., \& Viru, M. (1999). Critical periods in the development of performance capacity during childhood and adolescence. European Journal of Physical Education, 4, 75-119.

94. Vorontsov, W.A. (1998). Development of basic and special endurance in age-group swimmers. The Australian swimming coaches and teachers association

95. Vrijens, J. (1978). Muscle development in the pre and post pubescent age. Medicine in Sport, 11, $152-158$.

96. Whitehead, M. (2013a). The History and Development of Physical Literacy. ICSSPE Buelletin“Physical Literacy", 65: 22-28.

97. Whitehead, M. (2013b). The History and Development of Physical Literacy. ICSSPE Buelletin"Physical Literacy", 65: 29-34.

98. Whithall, J. (2003). Development of locomotor co-ordination and control in children. In G. J. P. Savelsberg, K. Davids, \& J. Van der Kamp (Eds.), Development of movement coordination in children: Applications in the field of ergonomics, health sciences and sport (pp. 251-270). London: Routledge.

99. Williams, C.A., Armstrong, N.\& Powell, J. (2000). Aerobic responses of prepubertal boys to two modes of training. British Journal of Sports Medicine, 34, 168-173.

100. Wylleman, P.\& Lavallee, D. (2004). A developmental perspective on transitions faced by athletes. In: Weiss MR (ed.) Developmental sport and exercise psychology: a lifespan perspective. Morgantown: FIT, pp.507-527.

Submitted: 10.11.2019.

Accepted: 09.12.2019.

Published Online First: 11.12.2019. 


\title{
ДУГОРОЧНИ РАЗВОЈ СПОРТИСТЕ, ОД ТЕОРИЈСКОГ И ПРАКТИЧНОГ МОДЕЛА ДО САЗНАЈНОГ ПРОБЛЕМА
}

\author{
Роберт Ропрет, Бранислав Јевтић \\ Факултет спорта и физичког васпитања, Универзитет у Београду, Србија
}

\begin{abstract}
Сажетак
Две декаде од креирања и успостављања Дечијег спорта, као универзитетског предмета на Факултету спорта и физичког васпитања Универзитета у Београду, и његове пуне академске и практичне афирмације, отворило је питање ревизије и ширења теоријског и практичног контекста овог предмета, нарочито у простору сазнања које се односи на дугогодишњи развој спортисте (ДРС) и планирања каријере (проблем рада). Стога су се, као предмет ове анализе, наметнули теоријски и практични модели који се односе на ДРС, а у функцији теоријске и практичне верификације, односно у у правцу дефинисања контекста новог сазнајног проблема. Сажимањем обимне теоријске и практичне грађе дошло се до закључка да теорија спорта није кадра да сачини оквир за реалан, а још мање за целовит модел дугогодишњег развоја спортисте, због чега је као циљ овог рада издвојено теоријско и емпиријско кретање ка новој парадигми целовитог сагледавања ДРС кроз спорт. Суштинском и темељном анализом контекста репрезентативног модела, познатог по свом енглеском акрониму „LATD“ (Long Term Athlete Development), као и других модела другогодишњег развоја спортисте, закључено је да се њихово полазиште мора успоставити око концепта “физичка писменост", као и да је истинитост модела ДРС, и даље, у поступку теоријске и практичне верификације. Понуђена расправа је оквир за нове искораке у приступу целовитој теорији и пракси спорта, нарочито у делу дечијег и спорта младих.
\end{abstract}

КљУчне речи: ДУГОГОДИШњИ РАЗВОЈ СПОРТИСТЕ / LATD / ТЕОРИЈСКЕ И ПРАКТИЧНЕ РЕДУКЦИЈЕ / ФИЗИЧКА ПИСМЕНОСТ

\section{УВОД}

Богата пракса спорта, као и резултати многобројних истраживања, указују да дете бављење спортом започиње, пре свега, због усавршавања постојећих и стицања нових спортских вештина, као и ради провода и забаве; дружења и стварања нових пријатељстава; узбуђења и изазова; постизања успеха - победе; стицања физичке кондиције; такмичења; наставка каријере ка вишем нивоу (Бачанац, 2011). Ово, као и многобројна друга и слична тврђења, сагледана у односу на предмет овог рада, а то су практични и теоријски модели дугорочног развоја спортисте у функцији новог сазнајног проблема, значе да је дечији узраст, у развоју човека, период током кога се стичу многобројна животна искуства и вредности кроз учешће у спорту. Физичко вежбање и физичка активност обогаћује дечије одрастање, подстичу развој многобројних атрибута и капацитета без којих, између осталог није могуће планирати, самим тиме ни прећи на следећи корак спортске каријере (Јевтић и Ропрет, 2011). Сходно предмету овог рада, и теорија, као и пракса потврђују да се до успеха у спорту долази кроз процес планирања дугогодишњег развоја.

Теорија спорта се, на неки себи својствен начин, бави питањима развоја и каријере спортисте, и при томе се занемарује холистички контекст и смисао учења о-за-кроз кретање и вежбање. У неку руку, како у интерационалним, тако, и нарочито, у домаћим изворима, уочавају се многобројне редукције, за које се може рећи да су резултат студиозног бављења учешћа деце у спорту. Интензивније од учешћа, елаборирају се проблеми дечијег одрастања кроз спорт, као што 
Ропрет Р., Јевтић Б., Дугорочни развој спортисте..., ФИЗИЧКА КУЛТУРА 2019; 73 (2): 190-205

су недовољно учешће или превремено прекидање са бављењем спортом. У разумевању једних и других приступа, али пре свега због хуманизације дечијег одрастања кроз спорт, на Факултету спорта и физичког васпитања Универзитета у Београду, формиран је предмет Дечији спорт, који под својим мотом „Дечији спорт од праксе до академске области“ доноси стручне и научне чињенице дечијег одрастања кроз спорт. Једна од области из програма овог предмета су и модели развоја детета кроз спорт. Две декаде од креирање Дечијег спорта, као универзитетског предмета, и његове пуне академске и практиче афирмације, поставља се питање теоријске заснованости и практичне целисходности постојећих модела дугогодишњег развоја спортисте, који као когнитивни изазов, представљају проблем овог рада.

Повод за расправу о проблему овог рада су механистичка преузимања понуђених модела дугогодишњег развоја спортисте од стране многих националних система спорта, истраживачких и педагошких инситуција. Тиме су изостале или занемарене расправе о истинитости модела који су успостављени на теоријским и практичним редукцијама. Сходно дефиницији која моделовање, као методу сазнања, види као умањену слику оригинала, очито је да је ниво апстракције (упрошћавања) реалног система дугогодишњег развоја спортисте, утицало на валидност понуђених модела. С тим у вези, опортуно је поставити питање успешности представљања структурно, организационо.... комплексног система развоја човека кроз спорт, преко модела. О истом се спроводе интензивне расправе кроз референтне научне часописе и документа из праксе спорта. Сажимање обимне теоријске и практичне грађе која је предмет анализе овог рада, све упућује да теорија спорта није (била) кадра да сачини оквир за реалан, a још мање за целовит модел дугогодишњег развоја спортисте. Другим речима, за понуђене теоријске и практичне моделе не може се рећи да не представљају реалан когнитивни и практични систем, како по броју и релевантности чинилаца структуре, тако и броја чињеница којима би било могуће устврдити постојање веродостојности оригинала и модела. Ипак, и без обзира на сазнајну целовитост, понуђени модели, као контекст стручног и оперативног планирања, постали су помоћ тренерима и креаторима политике развоја спорта у њиховој мисији да помогну деци и младима да се развијају кроз спорт, испоље и вреднују своју надареност за спорт. Са друге стране, недовољно продуктиван систем рада у спорту може подстаћи „испадање“ деце из спорта, повреде и потрошен таленат. У складу са тиме, циљ овог рада је да предложи неке одговоре од значаја за кретање ка теоријској парадигми целовитог сагледавања дугогодишњег равоја кроз спорт.

\section{МОДЕЛ ДУГОРОЧНОГ РАЗВОЈА СПОРТИСТЕ - ТЕОРИЈСКА И ПРАКТИЧНА КОНТРАВЕРЗА И-ИЛИ НОВА САЗНАЈНА ПАРАДИГМА}

Израда и примена модела дугогодишњег развоја спортисте - ДРС није нови стручни искорак. Ипак, један од постојећих модела, познат по свом енглеском акрониму - LTAD (енг. Long Term Athlete Development -LTAD) афирмисан од стране Иштвана Балаја (Istvan Balyi), као да доминира овим периодом развоја спорта. Иницијално је постављен као програм развоја канадског олимпијског тима алпских скијаша. Од почетног нацрта, врло брзо се развио у опште прихваћен модел планирања развоја младих спортиста у великом броју спортова. Прихваћен је од стране великог броја других националних система, између осталих Канаде, САД, Велике Британије, Ирске, Аустралије, Новог Зеланда и других. Наредним корацима на развоју овог модела, изворни контекст је редефинисан и допуњен резултатима истраживања психолога Андреаса Ериксона (Ericsson, Krampe \& TeschRome, 1993; Ericsson, 2006, 2008). Према Балају и Хамилтону (Balyi \& Hamilton, 2004) изворни модел представља „оквир“ који се прилагођава и организује према параметрима раста и развоја детета. Успостављен на дедукованим принципима узраста (хронолошког, биолошког, анатомског, спортског) и атрибута раста и развоја, LTAD је сачињен као вишестепени прогресивни модел (6 до 8 нивоа) у зависности од спортске гране. Подела на нивое у првом кораку била је организована око двогодишњих периода хронолошког узраста (од по две године, од шесте до 18-те године живота), а потом настављена кроз периоде до краја престанка активне спортске каријере, односно кроз опционе 
периоде целоживотног бављења различитим формама спорта. Накнадним разрадама модела и његовом применом у другим спортовима, извршено је сажимање првих фаза на сегменте од по три године хронолошког узраста (6-9, 9-12, 12$15,15-18)$, односно наставком каријере у узрасту 18 и старији. Задатак ДРС модела је да омогући да се развију основне моторичке способности у својој оптималној фази физичког развоја, а на основу претпоставке да су базичне моторичке вештине усвојене и да млади спортиста ефикасно и економично изводи исте. Свака од фаза LTAD је, како и следи, јасно дефинисана у смислу моторичког, когнитивног и психо-социјалног развоја (Balyi, 2001):

1. Развој основа (дечаци 6-9, девојчице 5-8 година) - Развој способности и вештина кроз забаву и игру: АБЦ спорта (агилност, равнотежа, координација, брзина); ТБЦ енг. РТЈ (трчање, бацање, скакање), КПУО - енг. KGBS (осећај средине, клизање, пловност, ударања/одбијања) и ХБШ - енг. СРК (хватање, бацање, шутирање).

2. Учење тренирања (дечаци 9-12, девојчице 8-11 година) - Развој способности кроз вежбе усмереног, полуспецифичног и специфичног карактера. Однос тренинга и такмичења је 70:30\%. Сматра се за кључну фазу у развоју координације.

3. Тренирања способности (девојчице 11-14, дечаци 12-15 година) - Индивидуализација тренинга, прилагођавање тренинга различитом степену зрелости. Однос тренинг -такмичења је 60:40\%.

4. Тренинг за такмичење (дечаци 15-18, девојчице 14-17 година) - Интензификација тренажног оптерећења. Индивидуализација према спорту, позицији у тиму, такмичарској дисциплини. Однос тренинга и такмичења са тренинзима такмичарскоспецифичног садржаја је 40:60\%.

5. Тренирање за победу (18 и више година) - Достизање физиолошког генетског капацитета. Однос тренинга и такмичења са тренинзима такмичарско-специфичног садржаја је 25:75\%.

Прелазак у наредни ниво каријере подразумева овладавање програмским задацима претходног нивоа (исходно планирање и тренирање-уче- ње). Циљ сваког модела ДРС је да се кроз рад, примерен узрасним карктеристикама деце, омогући постепен развој и достизање датог нивоа спортисте, без негативних последица ране специјализације, повређивања и напуштања спорта. Један од објективних физиолошких параметара, на основу кога се врши праћење, прилагођавање и евалуација програма према узрасним карактеристикама појединца, односно индивидуализација програма, заснован је на динамици параметара раста (пик брзине прираста телесне висине - енг. РВ и пик прираста мишићне масе -енг. РВМ). Модел ДРС који је данас оперативан, али истовремено и оспораван, заснива се на следећим постулатима (Balyi \& Hamilton, 2004):

- минумум 10 година или 10.000 сати да би се достигао ниво елитног спортисте (Bloom, 1985; Ericsson et al., 1993; Ericsson \& Charness, 1994);

- поштовање карактеристика „хронолошког“ и „биолошког“ развоја. Праћењем параметара телесне висине евидентирају се деца која раније (акцелеранти) или касније (ретарданти) улазе у пубертет;

- прилагођавање циљева и садржаја тренинга фазама пријемчивости тзв. „прозора трениабилности“ (window of trainability) одређеног система за тренажне стимулусе (Canadian sport for life, 2015, стр. 32). „Прозор тренирабилности “ је омеђен периодима одређеног трајање и испуњен циљевима усмереног моторичког развоја. Тако, ако се одређени период пропусти, а садржаји за развој способости нису примењени, спортиста неће бити кадар да достигне своје максималне потенцијалне способности (Balyi \& Hamilton, 2004);

- развој основних, базичних вештина на принципима разноврсности уместо ране специјализације. Нагласаку ЛТАДјена раном развоју способности и вештина заснованих на раду управљачког механизма, односно, централног нервног система (све форме координације и брзине, покретљивост, агилност) у фазама пре пубертета (до 12. године, фазе 1 и 2.);

- обим такмичења прилагођен обиму тренинга усмереног на развој технике и основних моторичких способности (велики обим 
Ропрет Р., Јевтић Б., Дугорочни развој спортисте..., ФИЗИЧКА КУЛТУРА 2019; 73 (2): 190-205

такмичења у пракси условљава и велики обим тренинга специфично такмичарског типа, на рачун развоја општих пособности, а нарочито технике);

- примена садржаја тренинга у форми забаве и задовољства;

- поштовање особености развоја дечака и девојчица;

- афирмација физичких, социјалних и психолошких потреба младих;

- успостављеност на 4 до 8 фаза у зависности од спорта (рана или касна специјализација).

Упркос томе што је широко прихваћен, ипак, модел ДРС пролази кроз критике једног броја истраживача (Lang \& Light, 2010; Ford, De Ste Croix, Lloyd, Meyers, Moosavi, Oliver, Till \& Williams, 2011; Kiely, 2012; Afonso, 2014; Ackerman, 2014; Côté\& Vierimaa, 2014;Coutinho, Mesquita, Fonseca \&De Martin-Silvaet, 2014; Van Kooten, 2016). Тукер (Tucker, 2013) тврди да, иако објашњење модела звучи концептуално јасно, ипак ДРС није у потпуности доказан, док Балај и сарадници (Bailey, Collins, Ford, MacNamara, Pearce \& Toms, 2010) имплицитно тврде да ДРС није прошао процесе провере којима се осигурава квалитет који је повезан са академским начелима. Наводе да је многим изворима на којима се заснива модел Балаја тешко присутпити, јер многи потичу из бившег Совјетског Савеза. Форд и сарадници (Ford et al., 2011) критикују модел ДРС као превише једнодимензионалан, и при томе наводе недостатак емпиријских доказа на којима се модел заснива. Ови аутори сугеришу да су „интерпретације модела ограничене јер се подаци на којима се заснивају ослањају на упитне претпоставке и погрешке метода сазнања. Поред тога, они сугеришу да ДРС перцепира генерички модел, а не индивидуализован план развоја спортисте.

\section{ТЕОРИЈСКЕ РЕДУКЦИЈЕ У МОДЕЛОВАЊУ ДУГОГОДИШЬЕГ РАЗВОЈА СПОРТИСТЕ}

Једна од слабости Теорије спорта проистиче из њеног једностраног сагледавања учења у спорту. Наиме, њом доминира само моторичко учење које она представља кроз две фазе. Прву која је усмерена ка формирању опште моторичке базе, и другу која је усмерена на тренинг и такмичења у датој спортског грани. Очито је да се ова редукција теорије спорта налази и у моделима развоја спортисте! Иста се пресликава у једностраном приступу поставци контекста учења о-за-кроз кретање, али и у разумевању чињенице да спорт мења природу детета, како у моторичком, тако и у социјалном, когнитивном, афективном простору. Могуће је да је ова редукција Теорије спорта хотимична и да је настала услед потребе да се тренерима осветли само један простор учења детета. Редукција може бити и резултат недовољне интегралности спортских наука и њених дисциплина. Како год, може се рећи да теорија спорта одступа од једног од сопствених принципа, а који се тиче нелинеарне природе развоја моторике и капацитета који опредељују успех у спорту. Епилог је тај да сама теорија спорта не афирмише значај и удео физичке активности, вежбања и спорта у развоју детета, да занемарује или не препознаје значај сензомоторних стимулација у развоју апстрактног мишљења, које заједно са социјалним учењем утиче на интелектуални развој (условно не препознаје теорију Пијажеа о интелектуалном развоју).

Задржавајући се унутар простора ове редукције, треба истаћи да је циљ прве фазе у моторичком развоју детета „опробати се у спорту“" и овладати вештинама и навикама из моторичког, когнитивног, социјалног, афективног простора. Исход ове фазе, могао би се изразити као „физичка писменост“ (physical literacy)1), који, суштински садржи мотивацију, самопоуздање, физичке способности, знање и разумевање за вредновање и учешће у физичкој активности (Whitehead, 2013a). Философски гледано, појам “физичка писменост" обухвата афективну, физичку и когнитивну карактеристику људске природе, при чему би, усмереност на само једну од карактеристика развоја, не би представљало „физичку писменост“ (Whitehead, 2013b). На личном плану детета, “физичка писменост” има вредност у неговању и афирмацији оних (сп)

1) “Физичка писменост" представља педагошки концепт који је усмерен ка усвајању основних вештина у кретању и основних спортских вештина које детету обезбеђују самопоуздање и контролу у широком спектру физичких активности, ритмичких (плесних) и других ситуација у животу. У „физичку писменост“ је укључена способност препознавања окружења, као и активности и реаговања које је адекватно ситуацији (Higgs, Balyi, Way, Cardinal, Norris \& Bluechardt, 2008) 
особности и вештина које имају потенцијал да побољшају и обогате квалитет дечијег одрастања и био-психо-социјалног сазревања, без којих се не бисмо могли развијати као људска бића и деловати у складу са нашим другим могућностима (Almond, 2013).

За анализу о проблему овог рада, интересантно је да теорија физичког васпитања препознаје стицање моторичке компетентности која је позитивно повезана са здравственим бенефитима, склоностима и навикама за целоживотно вежбање. Ипак, у доласку до ових циљева, сама теорија физичког васпитања се ослања и афирмише садржаје из одабраних спортских грана, занемарује моторичку, методичку и организациону сложеност и непримереност истих хетерогеној групи, каква су ученици, чиме, непотребно усложњава или одлаже процес целовитог описмењавања кроз овај наставни предмет. За разлику од горе поменутих теорија, резултати научних истраживања, недвосмислено указују да би напредак према исходима прве фазе моторичког учења, у хуманој и детету оријентисаној теорији спорта, треба успоставити око подстицања развоја осталих простора развоја детета (интегрални развој детета). Стога, очито је постојање унутар теоријске и међу теоријских дисонанци, као и „пукотина“ у преносу резултата истраживачких студија у праксу спорта и физичког васпитања! 3бог наведеног је важно целисходно поставити модел ДРС, а његову мисију успоставити ка “физичкој писмености” као педагошком исходу учешћа у спорту. Сагледано из перспективе ДРС, „физичка писменост" је исход кога описује овладаност (моторичким) знањима за која нема недоумица да су претходница и предуслов за усвајање и ефикасно извођење вишенаменских кретања која су садржана у специфичностима спортских грана и дисциплина (Kirk \& Rhodes, 2010).

Теорија спорта прву фазу моторичког развоја препознаје и као период током кога се велики број деце укључи у овладавању изазовима неких од понуђених спортова, али и као период у моторичком развоју током кога се региструје висок степен одустајања и тзв. испадања из спорта због деловања чинилаца различитог порекла, међу којима се региструју и различите форме злостављања. Другим речима, код већине деце, ова фаза је уједно и крај учешћа у неком од започетих спортова или спорту уопште, сходно чему се намећу не само питања о овладаности моторичким знањима пре „испадања из спорта“ већ, и пре свега, моторичке компетентности за целоживотно вежбање и активни животни стил. Ништа мање није важан ни одговор на питање о овладаности вештинама, развијености способности, усвојености навика и умења којима би се олакшало учешће детета у неком другом спорту (исходна оријентација дечијег спорта у функцији ДРС). У прилог овоме су и подаци истраживања спроведеног од стране Олимпијског комитета САД које је указало да је већина олимпијаца САД са краја XX века, учестовала у већем броју спортова, пре финалног избора спорта у коме су остварили успех на олимпијским играма. Утврђен је однос 88:12\% код мушкараца у корист већег броја спортова или, како се наводи, $88 \%$ спортиста се опробало у неком од спортова, пре учешћа у главном спорту. Овај однос код девојака је 83:17\%. Укупно 97\% испитаника, учесника ОИ, сматра да је учешће у више спортова било веома значајно за каснији успех у каријери (Gibbons, Hill, McConnell, Forster\& Moore,2002).

Намеће се закључак да теорија спорта није јасно профилисана у простору дечијег одрастања кроз спорт, да је затворена у принципе и правила која се односе на спорт одраслих, да занемарује атрибуте, потребе као и право детета на транзицију кроз спорт на путу развоја за живот.

\section{ПРАКТИЧНЕ РЕДУКЦИЈЕ У МОДЕЛОВАҢУ ДУГОГОДИШЊЕГ РАЗВОЈА СПОРТИСТЕ}

Сажимањем сазнања из спорта, дефинисањем циљева и задатака, садржаја и исхода дечијег одрастања и учешћа у спорту, у стручној литератури је ДРС представљано у виду модела програма развоја који се одвија кроз одређене фазе. Разлог за формирање модела ДРС, кога описују фазе и периоди, од оне која се назива од „опробавања“ до „отелотворења“ и укључења у спорт (фаза стицања), преко развоја перформанси (развојна фаза стечених атрибута) које воде до врхуских резултата у спорту (тренажно и такмичарско савршенство) је покушај да се целовито сагледају чиниоци развоја спортисте, као и да се програм развоја одвија 
Ропрет Р., Јевтић Б., Дугорочни развој спортисте..., ФИЗИЧКА КУЛТУРА 2019; 73 (2): 190-205

на систематизован и плански начин. О начину како достићи ниво врхунског спортисте, како одржати тај ниво (елитни спортиста) и који су то атрибути кључни за достизање успеха бавили су се многобројни истраживачи (Bloom 1985; Lazlo 1986; Stambulova, 1994; Salmela, 1994; Voronzov, 1998; Platonov, 1999; Wyllemand \& Lavallee, 2004). Формирајући одређене теоријске генерализације по овом питању, аутори су креирали моделе које су засновали на принципима развоја тренажне каријере. У зависности од аутора, развој од почетника до врхунског спортисте се одвија кроз већи број фаза, које броје од минимум три (почетна, развојна, перфекција), пет (припремна, почетак специјализације, интензиван тренинг у изабраном спорту, фаза кулминације, фаза дисконтинуитета у тренингу), до седам (активни почетак и забава, фаза основе; учење тренирања; тренирање за такмичења; тренинг за победу, одржавање врхунског нивоа, целоживотно бављење спортом). Код појединих аутора се уочава и до 10 фаза у моделу развоја од почетка до врхунског резултата и његовог одржавања. Без обзира на број фаза у моделу развоја, цитираност и ауторитет самих аутора, ипак, може се закључити да у свим наведеним и анализираним студијама, доминирају трагања за одговором на једно од два питања, а то су таленат спортисте и транзиција каријере спортисте. Када се овакав приступ сагледа у односу на теорију транзиције Шлосберга (Schlossberg, 1981), тада се за све наведене ауторе може рећи да су дедуковане и генерализоване моделе ДРС, успоставили, искључиво на теорији и пракси из простора транзиције и каријере, односно да су у свом емпиријском и теоријском раду били једнострани јер су занемарили преостала три, конститутиента теорије Шлозберга (ситуација, биће-self и подршка). Другим речима, могло би се прихватити да се један од извора поменутих практичних и теоријских редукција ДРС налази у недовољном интердисциплинарном и мултидисциплинарном препознавању и сарадњи.

Анализирани модели ДРС, када се сагледају у њиховој оријентацији према доласку до резултата у врхунском спорту, карактеришу два приступа, онај који се реализује кроз рану специјализацију и доминацију специфичних тренажних средстава и други, који упућује да се до успеха стиже кроз разноликост метода и средства у тренингу. Модел кроз рану специјализацију се јавља у техничко комплексним спортовима у којима се врхунско извођење може достићи и пре пуне физичке зрелости (спортска и ритмичка гимнастика, уметничко клизање, скокови у воду). Насупрот њему, модел кроз разноврсне активности и усмерену игру су чешћи у спортовима где се врхунско извођење достиже након пуне зрелости (пливање, дисциплине атлетике, борилачки спортови, спортске игре и други). У овом моделу специјализација се дешава у периоду од 13. до 15. године живота, а специфичан тренинг и тренинг који је усмерен ка постизању максималних способности након 16. године (Coutinho et al., 2016).

У контексту ове расправе важно је навести и модел ДРС који треба да сеуспостави око концепта „физичка писменост“" и који се као целоживотна вредност развија од узраста новорођенчета (рођење - четири године); детињства (пет до једанаест година); адолесценције (једанаест до осамнаест година); ране одраслости (осамнаест до 30 година); зрелости (30 - 65 година) до старије животне доби (65 година +).

Модели ДРС спортисте су сачињени и на основама когнитивне психологије и теорији учења моторичких вештина. Сходно томе, издвајају се два приступа у организацији стицања знања (Ericsson, 1993; Côté, Baker \& Abernethy, 2007; Côté, Murphy-Mills \& Abernethy, 2012; Côté, Erickson \& Abernethy, 2013; Ford, Hodges \& Williams, 2013; Moesch, Hauge, Wikman \& Elbe, 2013) кроз:

- усмерено вежбање (deliberate practice), које представља високо структуриране активности са јасним специфичним циљевима ка развоју способности, напорном тренингу, ниским ниовоом забаве и наглашеним нивоом концентрације, залагања, мотивације;

- усмерену игру (deliberate play) која подржава интринзично мотивисане активности засновне на афективној страни вежбања.

Концепт усмереног вежбања води ка раној специјализацији, усмерењу само према једном спорту и активностима које директно опонашају средства и методе тренинга врхунског спорта, и са очекивањем да млади спортиста, рано укључен у велики обим специфичног рада, тиме гради шансе да се развије у спортисту елитног нивоа. 
Рано усмеравање и специјализација најчешће карактеришу садржаји без забаве и уживања у вежбању. Последице оваквог приступа могу негативно утицати на мотивацију, психолошки и физички замор, повређивање и одустајање од даљег бављења спортом (Baker, 2003; Baker, Cobley \& Fraser-Thomas, 2009; DiFiori, Benjamin, Brenner \& Gregory, 2014).

Концепт усмерене игре се заснива на разноликости у примени моторичких садржаја које карактеришу активности са акцентом на забави. Примењује се у раној фази спортског развоја. Истраживања Хајмана и сарадника (Hayman, Polman, Taylor, Hemmings \& Borkoles, 2011; Hayman, Borkoles, Taylor, Hemmings \& Polman,2014), Кутиња и сарадника (Coutinho et al., 2014), Bejkera i sar., (Baker, Côté \& Deakin,2005) и Мемерта и сарадника (Memmert, Baker \& Bertsch,2010) указују да спортисти који су правовремено укључени у разноврсне моторичке активности (усмерена игра) могу достићи ниво врхунског спортисте. Правовремено учешће у разноврсним спортским активностима омогућава младима стицање различитих физичких, когнитивних, афективних и психолошких вештина и способности које могу имати позитиван трансфер на каснију специјализацију спортисте (Baker, Côté \& Abernethy, 2003; Côté, Lidor \& Hackfort, 2009). У наведеном концепту остаје нејасно да ли се, и на који начин долази до трансфера научених вештина на друге животне активности!

Анализа модела указује да је мали број аутора који је дао целовит когнитивни модел ДРС, који би био успостављен око чињеница којима се дати концепт може применити у датом спорту. Нису јасни ни параметри на основу којих се може вршити процена напредовања и напредовања на атрибутивној и скали спортске компетентности. Услед тога се рана специјализација, често погрешно тумачи и изједначује са усмереном праксом, док се рана разноврсност изједначује са усмереном игром. У теорији ови појмови су јасно разграничени и могу бити у интеракцији (коегзистенцији).

Модели развоја спортисте су своју примену остварили кроз различите форме планског развоја спортиста, од почетника до врхунског резултата. На основу анализе једног броја радова (Bloom, 1985; Salmela, 1994; Stambulov, 1994; Côté, 1999; Wylleman \&Lavallee, 2004; Abbott \&
Collins, 2004; Bailey \& Morley, 2006; Bruner, Erickson, Wilson \& Côté, 2010) издвојена су два главна концепта која се могу представити као два субмодела, и то онај који се тиче развоја талента и транзиције талената. Субмодел развоја талента представља вишестепени, прогресивни конструкт који описује промене у развоју спортисте. Бејли и Морли (Bailey \& Morley, 2006) наводе да исти мора бити мултидимензиона форма у коју су укључени утицаји интерперсоналних, интраперсоналних, когнитивних и креативних способности. Исти аутори, као слабост наводе недостатак информација које се односе на квантификацију компоненти сваке фазе, као и да је многе компоненте тешко или готово немогуће тестирати.

\section{КОНЦЕПТУАЛНИ МОДЕЛИ ДУГОГОДИШњЕГ РАЗВОЈА СПОРТИСТЕ}

Концептуални модели настају на основу препознавања јасне структуре, логике функционисања неког практичног и теоријског система. Они су и структурни модели с' обзиром да указују на структуру система те су, као такви, прилагођени као средство за комуникацију унутар струке. Као значајне концептуалне моделе развоја спортисте новијег датума, у литератури се наводе:

1. Модел фаза основа-талента-елитног и мастер нивоа (eng. Foundation, Talent, Elite, Mastery - FTEM) - (Gulbin, Croser, Morley \&Weissensteiner, 2013),

2. Модел развоја кроз учешће у спорту (eng. Development Model of Sport Participation, DMSP) - (Côté, Baker \& Abernethy, 2003 i 2007),

3. Модел транзиције спортске каријере (eng. Career Transition Model- CTM) - (Stambulova, 1994; Willeman \& Lavallee, 2004),

4. Дугогодишњи развој спортисте (eng. Long Term Athlete Development- LTAD) - (Balyi, 2001).

Модел FТЕМ садржи 10 јасно диференцираних нивоа. Недостатак овог модела је тај што недовољно уважава развојне процесе, нарочито код младих који касне у свом пубертетском развоју (Gulbin, Croser, Morley \&Weissensteiner, 
2013).

Модел DMSP настоји да јасно дефинише ограничења у развоју спортисте. Модел прати три форме учешћа у спорту: (1) рекреативно учешће у спорту кроз рану разноврсност у избору спортова и усмерене игре; (2) развој врхунских способности кроз рано учешће у разноврсним активностима и усмереним играма, и (3) развој врхунских способности кроз рану специјализацију и усмерену праксу. Квалитет овог модела је јасна идентификација индикатора за сваки ниво који су у сагласности са теоријама развоја деце и младих (Coutinho et al., 2014).

Модел СТМ, за разлику од претходних, јасно повезује узрочно - последичне везе у процесима, утицају на исходе, као и кључне елементе у процесима транзиције између пет нивоа.

За наведене концепте и моделе развоја спортисте, највећи изазов за истраживаче је да утврде критеријуме који дефинишу елитног спортисту, његов развој, степен његовог достигнућа и карактеристике које је потребно развијати и пратити. Јасним дефинисањем ових параметара избегла би се различита тумачења и проблеми у међусобном поређењу.

\section{Теоријска и практична упитаност о истинитости принципа LATD}

Оспоравања реалности функционисања LATD програма најбројнија су због недостатка научних истраживања идоказа на основу лонгитудиналних истраживања којим би се потврдили искази о периодима пријемчивности и њихове повезаности са узрасним периодима. Наведени недостаци ограничавају валидност LATD. Тврдње о психолошким и социјалним карактеристикама у појединим узрастима и њихова повезаност са успехом у спорту су утемељени на теоријским разматрањима без конкретних доказа (Tucker, 2013). Беилеј и сарадници (Bailey et al., 2010) су указали да су закључци о периодима пријемчивости („прозорима“) емпиријског карактера и да не постоје егзактни, чвршћи, експериментални докази. Аутори модела, Балаи и Хамилтон (Balyi \& Hamilton, 2004) лично су потврдили да је њихов рад резултат емпиријских посматрања. Знатно раније, Беунен и Малина (Beunen \& Malina,1996) су указали на евидентне варијације у развоју моторичких способности у зависности од степена раста и развоја, али да очигледно не постоји јасноћа у улози врсте и нивоа стимулуса на њихове промене. Тврдње да периоди пријемчивости имају одређено трајање (почетак и крај) и да су пропуштене фазе ненадокнадиве, такође су упитне јер успеси оних који су се касније укључили у спорт говоре против оваквих ставова (Viru, Loko, Harro, Volver, Laaneots \& Viru,1999; Van Kooten, 2016). Упитност ових ставова потврђују резултати испитивања 1720 америчких олимпијаца који показују да је просечна узрасна доб при уласку у спорт износила 11.4 године (Riewald, 2014).

Недостатак прихватљивих метода квантификације тренинга, педијатријских података, ширина апликативних стимулуса за веома широк спектар различитих спортова отежава могућности егзактног истраживања о ефекту стимулуса за развој способности, у вези са степеном раста и развоја (Ford et al., 2011).

Резултати појединих истраживања по овим питањима су контрадикторна. Једна говоре о „баријери вештине“ односно, да је напредак у развоју ка специјализацији и специфичним вештинама зависан од основних моторних шема развијених у раном узрасту (Gallahue \& Ozmun, 1998; Gallahue \& Donnelly, 2003). Друга, не подржавају ставове о условљености развоја способности и степена раста и развоја.

Са неуролошког аспекта, истраживања указују да мождана маса, свој пик развоја, достиже у периоду детињства (Rabinowicz, 1986) и да се узрасни периоди 6-8 и 10-12 година поклапају са периодима развоја моторичких способности (Higgs, Balyi, Way, Cardinal, Norris \& Bluechardt, 2008, Cratty, 1986). Међутим, евидентно је да се ради о периодима развоја (природни ток развоја), али без конкретних доказа да тај период представља период веће сензитивности и пријемчивости на стимулусе тренинга.

Истраживања о повезаности развоја аеробне издржљивости и периода пријемчивости (Jones \& Carter, 2000; Williams, Armstrong \& Powell, 2000; Mahon, 2008; Rowland, 1997; Viru, 1999) нису доказала директну повезаност развоја издржљивости са периодима пријемчивости. Највећи број показатеља развоја аеробне издржљивости је повезан са величином тела, развојем масе и композиције тела.

Периоди пријемчивости за развој брзине су такође остали без конкретних доказа, упркос 
бројним истраживањима (Beunen \& Malina, 1996; Viru, 1999; Whithall, 2003; Butterfield, Lehnhard, Lee \& Coladarci, 2004). Утврђено је да се промене у брзини дешавају, али да су повезане са биолошким, неуралним и биомеханичким факторима који се могу повезати, како са узрастом тако и сазревањем.

Проблемом објективног постојања фаза пријемчивости за развој јачине, бавило се више истраживача (Pfeiffer \& Francis, 1986; Vrijens, 1978; Lillegard, Brown, Wilson, Henderson \& Lewis, 1997) од којих је само један рад (Вријенс, 1978) указао на значајно повећање снаге у постпубертетском периоду (16,8 год.) у односу на претпубертетски период (10.5 год).

Мерења мишћне снаге указала су да тренинг утиче на побољшање снаге повећањем мишићне масе и мишићном синхронизацијом (Beunen \& Malina, 1988), али без доказа о повезности развоја са узрасним периодима. Закључак Форда и сарадника (Ford et al., 2011) је да су претпоставке на којима се занива LATD спекулативне и на жалост без емпиријских доказа.

\section{Изазови за верификацију и афирмацију концепта десет хиљади сати тренинга}

Један од првих постулата LATD, за успех у спорту и достизање врхунског нивоа, поребно је око 10.000 сати тренирања, односно 10 година (20 сати недељно). Правило је настало из истраживања Ериксона (Ericsson et al, 1993) о повезаности успеха студената виолине Академије у Берлину са просечним обимом од 10.000 сати вежбања до њихове 20. године старости. Истраживања из области спорта (Bloom, 1985; Ericsson \& Charness, 1994) указала су да је потребно 8 до 12 година тренирања талентованих спортиста за достизање новоа елитних спортиста. Подаци Олимпијског комитета САД истичу да је потребно 13 година тренирања за постизање резултата на нивоу учешћа у олимпијском тиму, а 15 година за освајање олимпијске медаље. Правило о 10.000 сати тренирања је постало опште прихваћено у готово свим моделима и варијацијама LATD модела. Критике на постулат о 10.000 сати су се односиле на недовољну научну и експерименталну доказаност података, као и да овај обим рада не мора нужно довести до постизања врхунског нивоа у спорту. На исказане критике, објашњење су изнели Ериксон и Пул (Ericcsson \& Pool, 2016) у коме је истакнуто да је истраживање 1993. године извршено на студентима виолине, који још увек нису врхунски музичари, већ само успешни студенти, а да врхунски музичари имају 30-так година и 20-25.000 сати вежбања; да се ради о просечним резултатима; да није у питању било какво вежбање, већ рад високог интензитета са високом мотивацијом и концентрацијом; да се не може очекивати да свако ко тренира 10.000 сати обавезно и достигне ниво елитног спортисте и да је схватање о већем значају усмереног рада од 10.000 сати у односу на генетске предиспозиције погрешно. Према Ериксону, правило 10.000 сати је погрешно протумачено, није се односило на спортске вештине и, у том смислу, није било научно доказано. Прихваћено је, јер је „деловало магично, респектабилно, са округлом цифром“ (Ericcsson \& Pool, 2016).

Истраживања једног броја истраживача (Helsen, Starkes \& Hodges, 1998; Baker et al., 2003; Soberlack \& Côté, 2003; Berry, Abernethy \&Côté, 2008) указала су да спортисти достижу врхунски ниво технике и раније, након 4000-6000 сати специфичног вежбања.

Према Такеру (Tucker, 2013) значајан недостатак LATD модела је што у не узима у обзир оне који касне у развоју, па је тиме принцип 10.000 сати нереалан.

\section{Учење технике кроз велики обим и низак интензитет}

Један од постулата LATD модела је да се у првим фазама (9-12 и 12-15 година) акценат ставља на развој технике и општих моторичких способности, односно на "физичку писменост“ уместо на такмичарски резултат. Пракса је показала да фокусирање тренера на резултат условљава повећање интензитета тренинга, што за последицу има занемаривање технике, а већи интензитет доводи до повећане могућности повређивања, претренираности, „менталног прегоревања“, одустајања (Lang \& Light, 2010).

Нажалост, погрешно тумачење препорука ЛТАД да је у млађем узрасту важан обим, а не интензитет тренажног оптерећења, довело је до израде неодговарајућих програма рада и препорука. Руководећи се препорукама о нагласку на обиму, а не интензитету тренинга, ASA (Amateur Swimming Association - UK) је препоручила 
Ропрет Р., Јевтић Б., Дугорочни развој спортисте..., ФИЗИЧКА КУЛТУРА 2019; 73 (2): 190-205

тренерима да, у другој фази програма (9-12 година), деца треба да препливају око 8000 метара недељно. Тренери су, концентришући се на овај задатак, као и због мањка термина тренинга, запоставили рад на техници (Moore, Collins \& Burwitz, 1998; ASA, 2003).

Више истраживача указује да погрешна примена тренинга великог обима утиче на: смањење обима тренинга технике и занемаривање чињенице да се основна техника развија при мањим брзинама покрета (Greyson, Kelly, Peyrebrune \& Furniss, 2010); повећавање ризика повређивања због преоптерећења (Abbott, Collins, Martindale \& Sowerby, 2002), физичког и менталног замора и „изгарања“ (Hollander, Meyers \& LeUnes, 1995), одустајање оних који не могу да прате овакво оптерећење (Salguero, Gonzalez-Boto, Tuero \& Marquez, 2003), као и проблем укључивања спортиста који касније улазе у пливачки спорт (Abbott et al., 2002). Као додатну критику оваквог начина рада Фаудеа и сарадници (Faude, Meyer, Scharhag, Weins, Urhausen \& Kindermann, 2008) наводе да велики обим тренинга, малог интензитета, усмерен на развој аеробних способности, веома мало утиче на активности у трајању од 20 секунди до 5 минута. Већина такмичарских дисциплина (80\%) у пливању не траје дуже од 5 минута и доводи у питање сврсисходност овог типа тренинга.

Према истраживањима Ланга и Лајта (Lang \& Light, 2010) тренери сматрају да смернице ЛТАД о изградњи пливача кроз тренинге са дугим дистанцама може да омете развој спортиста талентованих за краће дисциплине. Истраживачи се слажу да је, за напредовање у развоју, квалитет вежбања важнији од квантитета рада (Ford, Yates\&Williams, 2010; Low, Williams, McRobert \& Ford, 2013; Côté, Erickson \& Abernethy, 2013; Baker \& Young, 2014), да је техника кључ будуће спортске изврсности и предуслов за каснији развој специфичних вештина (Gallahue, 1982; Moore et al.,1998; Schmidt \& Wrisberg, 2004; Bloom, 1985; Van Rossum, 2001).

Поређење обима тренинга различитих система (Велика Британија и Аустралија) указује да нема значајних разлика, да је аустралијски модел са већим распоном обима: за узраст у првој фази предвиђа недељни обим од 6-17,5 км, а британски 8-16 км недељно. За другу фазу обими се делимично разликују, аустралијски препоручује
14-36 км, а британски 24-32 км (Lang \& Light, 2010). Аутори закључују да је вероватна грешка у томе што тренери или примењују превелики обим или што нису интегрисали вежбе технике у тренинг.

\section{Однос тренинга и такмичења}

Критике спровођења модела LATD се односе и на обим такмичења, дисциплине и узраст такмичара. Један од примера је програм Британске пливачке асоцијације (ASA). Бил Свитенхам (Bill Sweetenham), директор Британског пливачког савеза је критиковао националне програме засноване на LATD моделу због великог броја такмичења (12) и неодговарајућег броја тренинга (Affolter, 2016). ASA је снизила минимални узраст за државна такмичења на узраст 10 година за девојчице и 11 за дечаке, из програма искључила трке на 50 и 100 м, а увела критеријуме трка на 200 м. Накнадно су уведене и дисциплине 800 и 1500 м за девојчице од 11 и дечаке од 12 година. Разлог за овакве промене је „недостатак у физичком развоју, потребан за правилно пливање спринта“ (Grange \& Gordon, 2004). Према мишљењу појединих аутора (Brandon, 2002; Maglischo, 2003) такмичења на деоници од 200 м су већи стрес него у случају спринта на краћим деоницама.

У анализи програма Канадске џудо федерације (Judo Canada NCCP Committee) Ван Кутен (Van Kooten, 2016) износи недоследности џудо LATD програма: $88 \%$ освајача олимпијских и светских медаља је ушло у спорт са 11 година, што значи да су „прескочили“ фазу 2 (најзначајнију) програма; програм прописује да млађи од 12 година треба да избегавају „специјализацију“, „негативна такмичарска искуства“, „поређење са другом децом“, као и да све активности треба да имају „форму игре и забаве“. Стога изненађује препорука програма да деца У7 и У9 треба да усвоје специфичне технике бацања, као и да прођу такмичења у клупској конкуренцији.

\section{Остали постулати LATD изложени критикама}

Неизоставни фактор у примени ЛТАД модела су тренери и родитељи. Блек и Холт (Black \& Holt, 2009), као и Ланг и Лајт (Lang \& Light, 2010), су утврдили да LATD програм пружа национални оквир за структуирање система за развој талената. 
Али не може се говорити о ширем прихватању и примени принципа LATD, осим као опште стратегије. Банак и cap. (Banack, Bloom\&Falcao, 2012) указују да осим што сматрају да је позитиван аспект што сви „говоре истим језиком“, позитивне ставове о LATD имају млади тренери са мање искуства и родитељи почетника, док искуснији тренери имају одређене резерве према моделу и у већој мери се придржавају личног искуства. Слагање са принципима програма исказују тренери који раде са децом млађег узраста, до 9 година (фаза основа), док тренери старијих узраста показују поменуту резерву према моделу.

Такође, проблем у испуњењу принципа спортског развоја представља императив околине на тренере да постижу резултате од ране доби, што доводи до тога да су деца која касне у развоју потиснута у процесу тренинга и селекције. Блек и Холт (Black \& Holt, 2009) сматрају да тренери не прихватају LATD модел због недовољне информисаности и едукације о његовој примени. Недовољна обученост и оспособљеност тренера се показала у непознавању принципа селекције, избора тестова и критеријума који, ако постоје, су различити од клуба до клуба и даље. Значајан недостатак се показао у повезаности система на клупском, регионалном и националном нивоу.

У реализацији принципа да успех у (пре) адолесцентском периоду није примарни задатак, доводи до тога да се многи тренери руководе традиционалним приступом да је успех (медаља) у раном узрасту једино мерило и доказ талента. За овакав приступ се оправдање налази у традицији спортске културе већина нација (Lang, 2009; Abbott et al., 2002) и претходном, личном искуству из праксе већине тренера (Gould, Gianinni, Krane \& Hodge, 1990; Gilbert \& Trudel, 2001; Cushion, Armour \& Jones, 2003; Black \& Holt, 2009).

Очигледно је да на примену LATD утиче слаба образованост тренера и недовољно знање из области значајних за квалитетан рад. Ровли (Rowley, 1994) истиче податак да 85\% фудбалских тренера не примењује никаква истраживачка средства за идентификацију талената. Тренери треба да се образују у погледу начина коришћења података које захтева LATD модел.

\section{ЗАКЉУЧАК}

I Анализа актуелних модела дугогодишњег развоја спортисте указује да, упркос напретку у сазнањима, теорија и пракса показују значајне разлике у приступу овом проблему. Недостатак лонгитудиналних истраживања, недовољно разрађен систем праћења, контроле и евалуације спортисте утиче на веродостојност понуђених модела дугогодишњег развоја. Један од модела дугогодишњег развоја, а то је LATD, креиран као водич-смерница у развоју појединца у складу са његовим биолошким, моторичким, когнитивним и психосоцијалним карактеристикама;

II Упркос широкој имплементацији, ипак, мало се зна о ефектима примене LATD модела у контексту појединачног случаја. Од момента његове имплементације до данас уочени су приступи којима се исти афирмише али и оспорава. Велики број детерминанти, пре свега индивидуална динамика и нелинеарност биомоторичког развоја детета-спортисте, захтевају лонгитудинални приступ сазнањима у односу на праксу истраживања временски зависних серија процене појединачних способности. Другим речима, неопходно је стварање когнитивног система којим би се верификовале индивидуалне и интеридивидуалне разлике у адаптацијама тренираних атрибута спортисте унутар специфичности дате спортске гране. Неодостајући теоријски и практични контекст бића појединачних спортских грана се намеће као ограничавајући фактор у верификацији теоријског и практичног значаја LATD-a.

III Неформиран шири програмски контекст LATD је под сталном анализом стручњака из различитих области наука које се баве дечијим одрастањем, и који, хронично, постављају питања научне истинитости и практиче примењивости модела, а унутар њега и:

○ термина, а потом и фазе пријемчивости у моторичком развоју детета-спортисте. Истраживања нису показала релевантне доказе о постојању ове фазе, док су поједи- 
на истраживања оспорила и њихову веродостојност;

○ тврдње о обиму тренирања потребном да се достигне ниво врхунског спортисте. Исте су оспорене због примене неадекватне методологије, сумње на спекулације у закључцима да спортисти са мањим обимом рада достижу жељени ниво;

○ препорука о предности обима тренажног оптерећења у односу на интензитет. Евидентна су погрешна разумевања у специфичности појединих моторичких способности.

IV Уочени недостаци овог и других модела ДРС проистичу из неадекватности у оперативном планирању примене до којих долази и услед (не)знања тренера о карактеристикама развоја дечијег организма, методама рада, принципима и методама селекције, па тако исти није понудио оријентацију праксе у: (1) раду са децом која касније улазе у фазу пубертет, (2) у раду се децом која у спорт улазе у каснијем узрасту.

V Моделу LATD се хронично постављају питања као што су:

a) Који су то фактори који, у наведеним околностима, омогућавају усвајање основних вештина и навика из моторичког, когнитивног, социјалног, афективног простора („физичка писменост“) и који су кључни за даљи напредак?

б) Да ли таленат појединца, утицај другог спорта или свакодневна физичка активност

\section{ЛИТЕРАТУРА}

1. Abbott, A. \& Collins, D. (2002). A theoretical and empirical analysis of a "State of art" talent identification. High Ability Studies, 13(2) 157-178

2. Abbott, A.\& Collins, D. (2004). Eliminating the dichotomy between theory and practice in talent identification and development: considering the role of psychology. J Sports Sci, 22: 395-408.

3. Abbott, A., Collins, D., Martindale, R. \& Sowerby, K. (2002). Talent Identification and Development: An Academic Review, Sportscotland, Edinburgh. y

окружењу („спорт у породици“, „спорт у дворишту“) утичу на „физичку писменост“ и креирање перформанси од значаја за наставак каријере и евентуални успех у врхунском спорту?

VI Целовитом анализом контекста LATD и других модела ДРС, уочава се да се њихово полазиште мора успоставити око концепта “физичка писменост".

VII Око „физичке писмености“ постоје различити теоријски и практични приступи одређења њеног бићи, значаја и модалитета развоја. Оно што је конкретно, односи се на неформалан ток њеног стицања током кога деца постижу прве и високо квалитетне вештине, способности, навике..., развијају карактер, афирмишу таленат. Насупрот томе су модалитети усмерене активности која се спороводи у физичком васпитању и спортским клубовима (формални систем). Неформални припада јединственом процесу стицања „физичке писмености“ као исходишта једне фазе развоја након које се планирају следеће фазе (стицања, развоја специфичних атрибута, тренажне и такмичарске изузетности) унутар неког од модела ДРС.

VIII Истинитост модела ДРС је, и даље, у поступку теоријске и практичне верификације. Понуђена расправа је оквир за нове искораке у приступу целовитој теорији и пракси дечијег и спорта младих.

4. Ackerman, P.L. (2014). Nonsense, common sense, and the science of expert performance: Talent and individual differences. Intelligence, 45, 6-17.

5. Afonso, J. (2014). Long-term athlete development model - A critique. Dostupno 5.9.2019 na: http:// www.youtube.com/watch? $\mathrm{v}=\mathrm{VVwPXcCWr8o \& fe}$ ature $=$ youtu.be

6. Affolter, F. (2016) Critical Analysis of LTAD model. dostupno 5.9.2019 na https://www.researchgate.net/publication/316513256_Critical_Analysis_of_LTAD_model . 
7. Almod, L. (2013). What is the Value of Physical Literacy and why is Physical Literacy valuable? ICSSPE Buelletin“Physical Literacy”, 65: 35-42.

8. Amateur Swimming Association (ASA) (2003). The Swimmer Pathway: Long Term Athlete Development, ASA, Loughborough.

9. Bačanac, LJ., Petrović, N., i Manojlović, N. (2011). Psihološke osnove treniranja mladih sportista. Beograd: Republički zavod za sport.

10. Bailey, R.\& Morley, D. (2006). Towards a model of talent development in physical education. Sport Educ Soc, 11: 211-230.

11. Bailey, R.P., Collins, D., Ford P.A., MacNamara, A., Pearce, G.\&Toms, M. (2010). Participant development in sport: An academic literature review. Commissioned report for Sports Coach UK. Leeds: Sport Coach UK.

12. Baker, J., Cobley, S, \& Fraser-Thomas, J. (2009) What do We Know about Early Sport Specialization? Not Much! High Abil Stud, 20: 77-89.

13. Baker, J.\& Young, B. (2014). 20 years later: deliberate practice and the development of expertise in sport. Int Rev Sport Exerc Psychol,7: 135-157.

14. Baker, J., Côté, J.\& Abernethy, B. (2003). Learning from the experts: practice activities of expert decision makers in sport. Res Q Exerc Sport, 74: 342-347.

15. Baker, J., Côté, J.\& Abernethy, B. (2003). Sportspecific practice and the development of expert decision-making in team ball sports. J Appl Sport Psychol, 15: 12-25.

16. Baker, J., Côté, J.\& Deakin, J. (2005). Expertise in ultra-endurance triathletes early sport involvement, training structure, and the theory of deliberate practice. J Appl Sport Psychol, 17: 64-78.

17. Baker, J. (2003). Early specialization in youth sport: a requirement for adult expertise? High Abil Stud, 14: 85-94.

18. Balyi, I. (2001).Sport system building and Longterm athlete development in British Columbia. Canada: Sport Med BC

19. Balyi, I. \& Hamilton, A. (2004).Long-Term Athlete Development: Trainability in Childhood and Adolescence. Windows of Opportunity. Optimal Trainability, National Coaching Institute British Columbia \& Advanced Training and Performance Ltd, Victoria, BC.
20. Banack, H., Bloom, G. \& Falcao W. (2012). Promoting long term athlete development in cross country skiing throught competency-based coach education: A quantitive study.International Journal of sport science and coaching. Vol 7 (2), 301-312

21. Berry, J., Abernethy, B.\&Côté, J. (2008). The contribution of structured activity and deliberate play to the development of expert perceptual and decision-making skill. J Sport Exerc Psychol, 30: 685-708.

22. Beunen, G., \& Malina, R. M. (1996). Growth and biological maturation: Relevance to athletic performance. In O. Bar-Or (Ed.), The child and adolescent athlete (pp. 3-24). Oxford: Blackwell.

23. Black, D.E. \& Holt, N.L. (2009). Athlete Development in Ski Racing: Perceptions of Coaches and Parents.International Journal of Sports Science \& Coaching, 4(2), 245-260.

24. Bloom, B.S., (1985). Developing Talent in Young People. New York: Ballantine.

25. Brandon, R. (2002). Why High-Intensity Training is a Better Model Than High-Volume Training for Swimmers, Especially Sprinters, Peak Performance, 167, 8-14.

26. Bruner, M., Erickson, K., Wilson, B. \& Côté, J. (2010). An appraisal of athlete development models through citation network analysis. Psychol Sport Exerc. 11: 133-139.

27. Butterfield, SA., Lehnhard, R., Lee, J.\& Coladarci, T. (2004). Growth rates in running speed and vertical jumping by boys and girls ages 11-13. Perceptual and Motor Skills, 99, 225-234.

28. Canadian Sport for Life (2015) dostupno 15.9.2019 na: www.canadiansportforlife.ca

29. Côté, J.\& Vierimaa, M. (2014). The developmental model of sport participation: 15 years after its first conceptualization. Science \& Sports, 29(S), S63-S69.

30. Côté, J., Baker, J.\& Abernethy, B. (2003). From play to practice: a developmental framework for the acquisition of expertise in team sport. In: Starkes J \& Ericsson KA (eds) Expert performance in sports: advances in research on sport expertise. Champaign: Humam Kinetics, pp.89-113.

31. Côté, J., Baker, J.\& Abernethy, B. (2007). Practice and play in the development of sport expertise. 
In: Eklund $R$ \& Tenenbaum $G$ (eds) Handbook of sport psychology. Hoboken: Wiley, pp.184-202.

32. Côté, J., Erickson, K.\& Abernethy, B. (2013). Play and practice during childhood. In: Côté J \& Lidor $R$ (eds) Conditions of children's talent development in sport. Morgantown: FIT, pp.9-20.

33. Côté, J., Lidor, R.\& Hackfort, D. (2009). ISSP position stand: to sample or to specialize? seven postulates about youth sport activities that lead to continued participation and elite performance. Int J Sport Exerc Psychol, 9: 7-17.

34. Côté,J., Murphy-Mills, J.\& Abernethy, B. (2012). The development of skill in sport. In: Hodges $N$ \& Williams AM (eds) Skill acquisition in sport: research, theory and practice. New York, NY: Routledge,pp.269-286.

35. Côté J. (1999). The influence of the family in the development of talent in sport. Sport Psychol, 13: 395-417.

36. Coutinho, P., Mesquita, I., Fonseca, AM.\&De Martin-Silvaet, L. (2014). Patterns of sport participation in portuguese volleyball players according to expertise level and gender. Int J Sport Sci Coach, 9: 579-592.

37. Cratty, B.J. (1986). Perceptual motor development in infants and children (3rd edn.). Englewood Cliffs, NJ: Prentice-Hall.

38. Cushion, C.J., Armour, K.M. \& Jones, R.L. (2003). Coach Education and Continuing Professional Development: Experience and Learning to Coach, Quest, 55, 215-230.

39. DiFiori, JP., Benjamin, HJ., Brenner, J.S.\& Gregory, A. (2014). Overuse injuries and burnout in youth sports: a position statement from the American medical society for sports medicine. $\mathrm{Br}$ J Sports Med, 48: 287-288.

40. Ericsson, K.A. (2006). Cambridge handbook of expertise and expert performance. New York: Cambridge University

41. Ericsson, K.A. (2008). Deliberate practice and acquisition of expert performance: A general overview. Academic Emergency Medicine, 15(11), 988

42. Ericsson, K.A, \& Charness, N. (1994). Expert performance: its structure and acquisition. Am. Psychologist, 49(8), 725-747

43. Ericsson, KA., Krampe, R.\& Tesch-Rome,C. (1993). The role of deliberate practice in the ac- quisition of expert performance. Psychol Rev; 100: 363-406.

44. Ericsson, A. \& Pool, R. (2016) Peak: Secrets from the New Science of Expertise. Houghton Mifflin Harcourt

45. Faude, O., Meyer, T., Scharhag, J., Weins, F. Urhausen, A. \& Kindermann, W. (2008). Volume vs. Intensity in the Training of Competitive Swimmers.International Journal of Sports Medicine, 29, 906-912.

46. Ford, P., Hodges, N.\& Williams, AM. (2013). Creating champions: the development of expertise in sport. In: Kaufman SB (ed.) The complexity of greatness: beyond talent or practice. New York, NY: Oxford University Press, pp.391-412.

47. Ford, P., Yates, I.\& Williams, AM. (2010). An analysis of practice activities and instructional behaviours used by youth soccer coaches during practice: exploring the link between science and application. J Sports Sci, 28: 483-495.

48. Ford, P., De Ste Croix, M., Lloyd, R., Meyers, R., Moosavi, M., Oliver, J., Till, K. \& Williams C. (2011). The Long Term Athlete Development model: Physiological evidence and application. Journal of sport Science, Feb. 15th; 29(4): 389-402

49. Gallahue, D.L. (1982).Fundamental Movement Experiences for Children, New York: Wiley.

50. Gallahue, D. \& Donnelly, F. (2003). Development of physical education for all children ( $4^{\text {th }}$ edn.) Champaign, Il: Human Kinetics

51. Gallahue, D.L. \& Ozmun, J.C. (1998). Understanding motor development. New York. Mc Graw-Hill.

52. Gibbons, T., Hill, R., McConnell, A., Forster, T., \& Moore, J. (2002). The path to excellence: A comprehensive view of development of U.S. Olympians who competed from 1984-1998. United States Olympic Committee

53. Gilbert, W. \& Trudel, P. (2001). Learning to Coach Through Experience: Reflection in Model Youth Sport Coaches.Journal of Teaching and Physical Education, 21, 16-34.

54. Gould, D., Gianinni, J., Krane, V. \& Hodge, K. (1990). The Educational Needs of Elite U.S. National Pan American and Olympic Coaches.Journal of Teaching in Physical Education, 9, 332-344.

55. Grange, J. \& Gordon, R. (2004). Success is Long Term: Long Term Athlete Development Related 
to the Journey Through Swimming, ASA, Loughborough.

56. Greyson, I., Kelly, S., Peyrebrune, M., \& Furniss, B. (2010). Research Notes: Interpreting and Implementing the Long Term Athlete Development Model: English Swimming Coaches' Views on the (Swimming) LTAD in Practice: A Commentary. International Journal Of Sports Science \& Coaching, 5(3), 403-406.

57. Gulbin, J., Croser, M.J., Morley, E.J. \&Weissensteiner JR. (2013). An integrated framework for the optimisation of sport and athlete development: a practitioner approach. J Sports Sci, 31: 1319-1331.

58. Hayman, R., Borkoles, E., Taylor, J.A., Hemmings, B.\& Polman, R. (2014). From pre-elite to elite: the pathway travelled by adolescent golfers. Int J Sports Sci Coach, 9: 959-974.

59. Hayman, R., Polman, R., Taylor, J., Hemmings, B. \& Borkoles, E. (2011). Development of elite adolescent golfers. Talent Dev Excell, 3: 249-261.

60. Helsen, W.F., Starkes, J.\& Hodges, N. (1998). Team sports and the theory of deliberate practice. J Sport Exerc Psychol, 20: 12-34.

61. Higgs, C., Balyi, I., Way, R., Cardinal, C., Norris, S.\& Bluechardt, M. (2008). Developing physical literacy: A guide for parents of children ages 0 to 12 . A supplement to Canada Sport for Life. Vancouver, British Columbia: Canadian Sport Centres

62. Hollander, E.B., Meyers, M.C. \& LeUnes, A. (1995). Psychological Factors Associated with Over-Training: Implications for Youth Sport Coaches,Journal of Sport Behaviour, 18, 3-20.

63. Jevtić, B. i Ropret, R. (2011). Dugoročno planiranje sportske karijere. U: Jevtić B, Radojević J., Juhas I., Ropret R (ur) Dečiji sport, od prakse do akademske oblasti. Beograd: Fakultet sporta i fizičkog vaspitanja, str 281-297

64. Jones, A.M.\& Carter, H. (2000). The effect of endurance training on parameters of aerobic fitness. Sports Medicine, 29, 373-386.

65. Kiely, J. (2012). Periodization paradigms in the 21st century: Evidence-led or tradition-driven? International Journal of Sports Physiology and Performance, 7, 242-250.

66. Kirk, M.A\& Rhodes, R.E. (2010). Occupation correlates of adults' participation in leisure-time physical activity: a systematic review.Am J Prev Med, Apr;40(4):476-85

67. Lang, M., (2009). Swimming in the Panopticon: An Ethnographic Study of Good Practice in Competitive Youth Swimming, PhD Thesis, Leeds Metropolitan University.

68. Lang, M. \& Light, R. (2010). Interpreting and Implementing a Long Term Athlete Development Model: English Swimming Coaches' Views on the (Swimming) LTAD in Practice, International Journal of Sports Science and Coaching, 5, 389402.

69. Lazlo, N. (1986). Il tempo di costuire. Rivista di cultura sportiva. SDS, 3-4, 6-10.

70. Lillegard, W.A., Brown, E.W., Wilson, D.J., Henderson, R.\& Lewis, E. (1997). Efficacy of strength training in prepubescent males and females: Effects of gender and maturity. Paediatric Rehabilitation, 1, 147-157.

71. Low, J., Williams, A.M., McRobert A. \& Ford, P. (2013). The microstructure of practice activities engaged in by elite and recreational youth cricket players. J Sports Sci, 31: 1242-1250.

72. Maglischo, EW. (2003). Swimming Fastest: The Essential Reference on Technique, Training and Program Design, Human Kinetics, Champaign, IL.

73. Mahon, A.D. (2008). Aerobic training. In N. Armstrong \& W. Van Mechlen (Eds.), Paediatric exercise science and medicine (pp. 273-286). Oxford: Oxford University Press.

74. Martindale, R.J., Collins, D. \& Abraham, A. (2007). Effective Talent Development: The Elite Coach Perspective in UK Sport.Journal of Applied Sport Psychology, 19,187-206.

75. Memmert, D., Baker, J.\& Bertsch, C. (2010). Play and practice in the development of sport-specific creativity in team ball sports. High Abil Stud, 21: 3-18.

76. Moesch, K., Hauge, M.T., Wikman J.M.\& Elbe, M. (2013). Making it to the top in team sports: start later, intensify, and be determined! Talent Dev Excell, 5: 85-100.

77. Moore, P.M., Collins, D. \& Burwitz, L. (1998).The Development of Sporting Talent 1997: An Examination of the Current Practices for Talent Development in English Sport. London: English Sports Council. 
78. Pfeiffer, R., \& Francis, R. (1986). Effects of strength training on muscle development in prepubescent, pubescent and postpubescent males. Physician and Sportsmedicine, 14, 134-143.

79. Platonov, N.V. (1999). La concezione della"periodizzazione" e lo sviluppo di una teoria dell 'allenamento. Rivista di cultura sportiva. SDS. XVIII(45), 3-7.

80. Rabinowicz, T. (1986). The differentiated maturation of the cerebral cortex. In F. Falkner \& J. Tanner (Eds.), Human growth: A comprehensive treatise, Vol. 2. Postnatal growth: Neurobiology (2nd edn., pp. 385-410). New York: Plenum.

81. Riewald, S. (2014). The Path to Excellence: A View on the Athletic Development of U.S. Olympians Who Competed from 2000-2012. USA Olimpic Committee.

82. Rowland, T.W. (1997). The "trigger hypothesis" for aerobic trainability a 14 -year follow-up (editorial). Pediatric Exercise Science, 9, 1-9.

83. Rowley, S. (1994). The British perspective: talent identification and selection - the future for British Governing Bodies. BOA CAG Seminar: London.

84. Salguero, A., Gonzalez-Boto, R., Tuero, C. \& Marquez, S. (2003). Identification of Dropout Reasons in Young Competitive Swimmers, Journal of Sports Medicine and Physical Fitness, 43(4), 530534.

85. Salmela, J. (1994). Stages and transitions across sports careers. In: Hackfort D (ed.) Psycho-social issues and interventions in elite sports. Frankfurt: Lang, pp.11-28.

86. Schmidt, R. \& Wrisberg, C. (2004).Motor Learning and Performance: A Problem-Based Learning Approach, Human Kinetics, Champaign, IL., 2004.

87. Schlossberg, N.K. (1981). A model for analyzing human adaptation to transition. The Counseling Psychologist, 9, 218

88. Soberlack, P.\&Côté, J. (2003). The developmental activities of elite ice hockey players. J Appl Sport Psychol, 15: 41-49.

89. Stambulova, N. (1994). Developmental sports career investigations in Russia: a post-perestroika analysis. Sport Psychol, 8: 221-237.

90. Tucker, R. (2013) Long term athlete development - Teh science of sport dostupno 15.9.2019 na https://sportsscientists.com/2013/02/long-term- athlete-development-foundations-challenges

91. Van Kooten, C. (2016). Re-consideration LTAD on coach education: An illustration from judo. International Sport Coaching Journal, (3), 83-89

92. Van Rossum, J.H. (2001). Talented in Dance: The Bloom Stage Model Revisited in the Personal Histories of Dance Students, High Ability Studies, 12, 181-197.24

93. Viru, A., Loko, J., Harro, M., Volver, A., Laaneots, L., \& Viru, M. (1999). Critical periods in the development of performance capacity during childhood and adolescence. European Journal of Physical Education, 4, 75-119.

94. Vorontsov, W.A. (1998). Development of basic and special endurance in age-group swimmers. The Australian swimming coaches and teachers association

95. Vrijens, J. (1978). Muscle development in the pre and post pubescent age. Medicine in Sport, 11, 152-158.

96. Whitehead, M. (2013a). The History and Development of Physical Literacy. ICSSPE Buelletin“Physical Literacy", 65: 22-28.

97. Whitehead, M. (2013b). The History and Development of Physical Literacy. ICSSPE Buelletin"Physical Literacy", 65: 29-34.

98. Whithall, J. (2003). Development of locomotor co-ordination and control in children. In G. J. P. Savelsberg, K. Davids, \& J. Van der Kamp (Eds.), Development of movement coordination in children: Applications in the field of ergonomics, health sciences and sport (pp. 251-270). London: Routledge.

99. Williams, C.A., Armstrong, N.\& Powell, J. (2000). Aerobic responses of prepubertal boys to two modes of training. British Journal of Sports Medicine, 34, 168-173.

100. Wylleman, P.\& Lavallee, D. (2004). A developmental perspective on transitions faced by athletes. In: Weiss MR (ed.) Developmental sport and exercise psychology: a lifespan perspective. Morgantown: FIT, pp.507-527.

Примљен: 10.11.2019.

Прихваћен: 09.12.2019.

Online објављен: 11.12.2019. 